E 360 .785

$x^{3}+2=$

ste

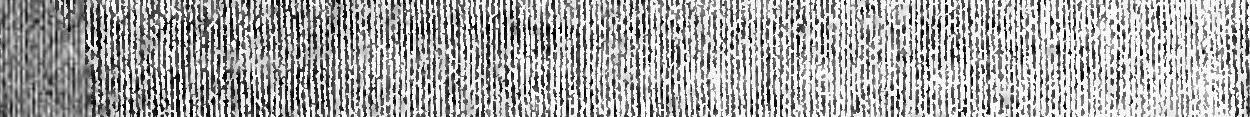

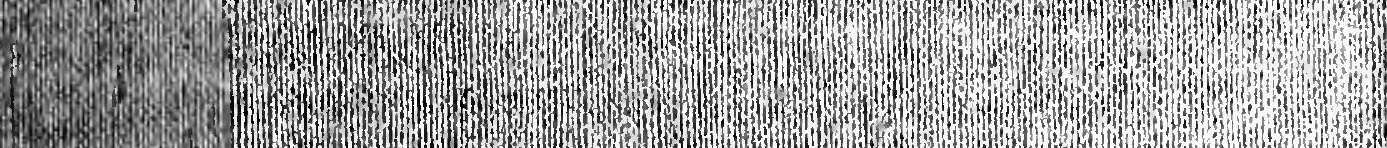

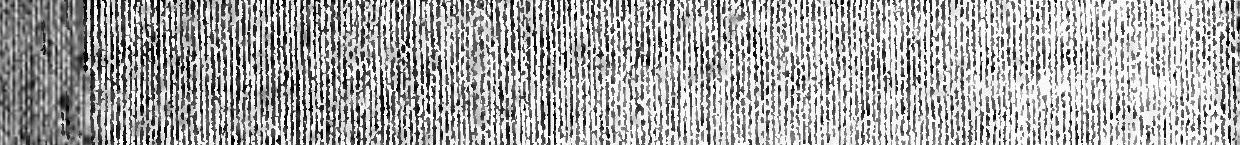

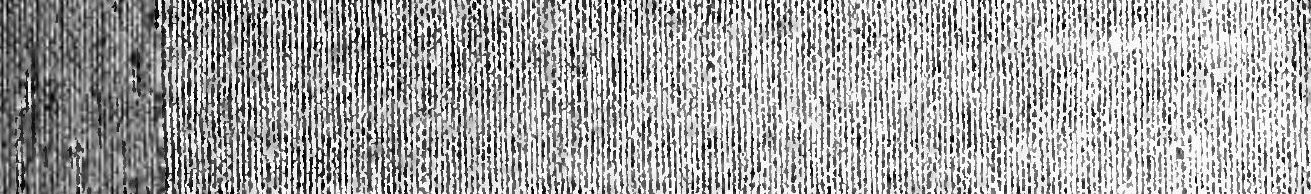
m. mom H.

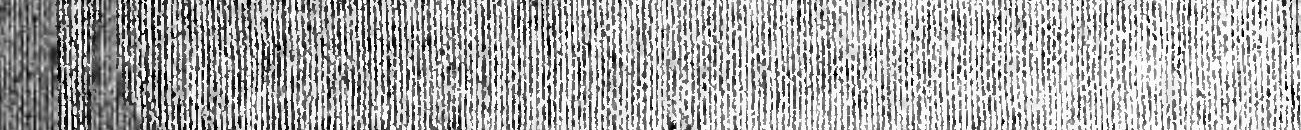

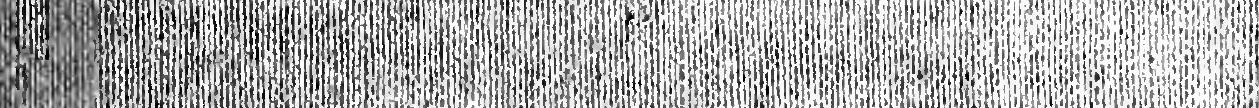

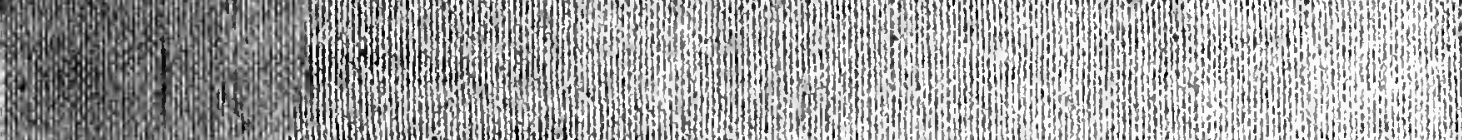
20.

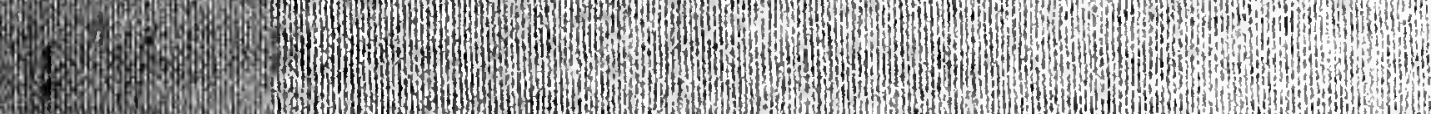

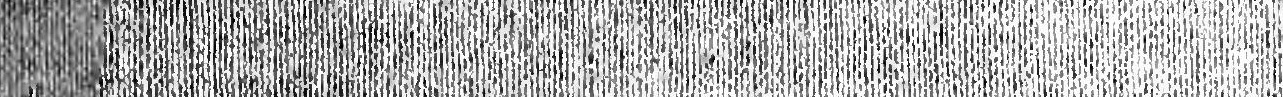

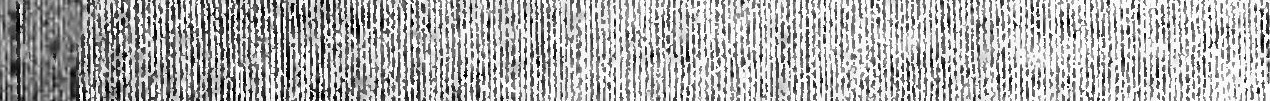

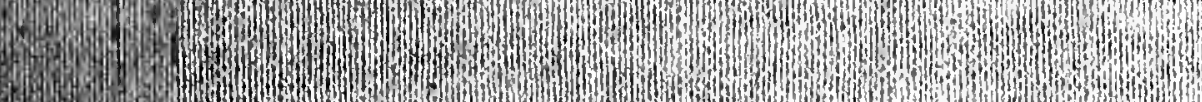

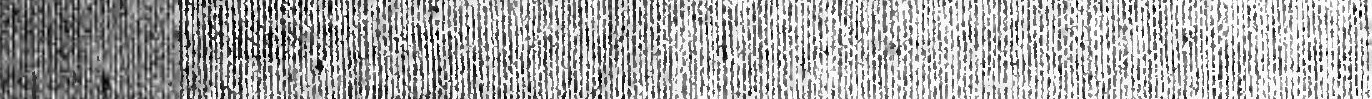
-

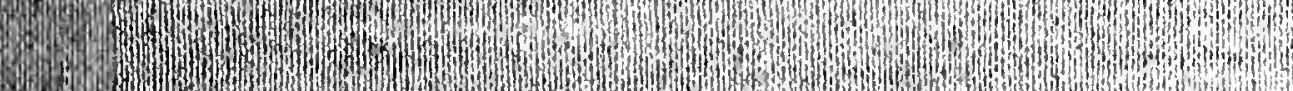

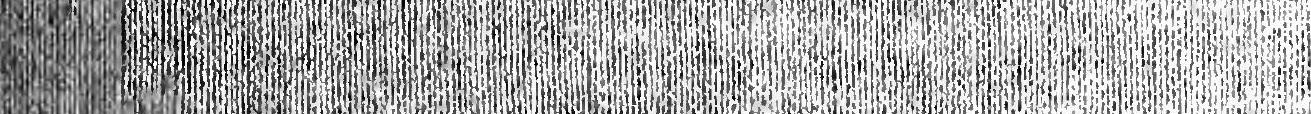

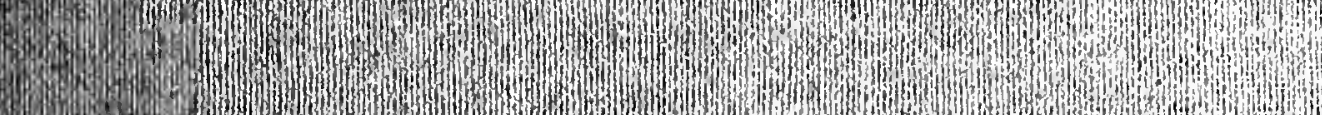

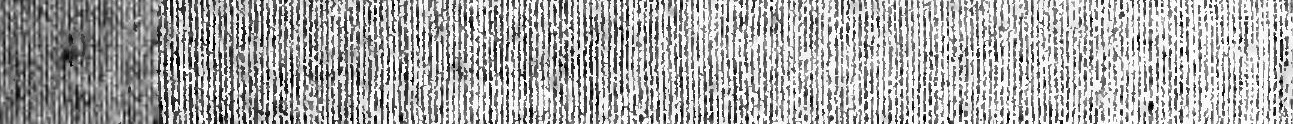

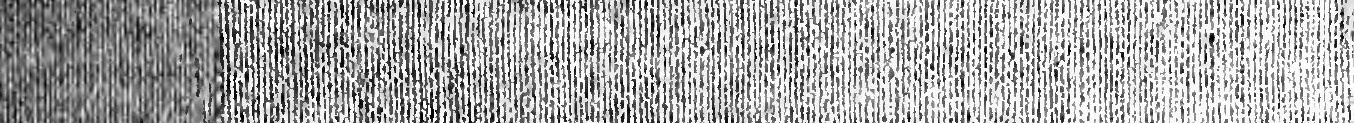
16-2. -

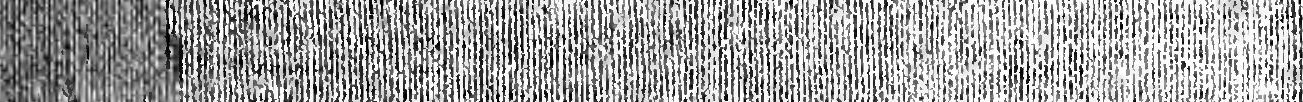
-2.m. a.

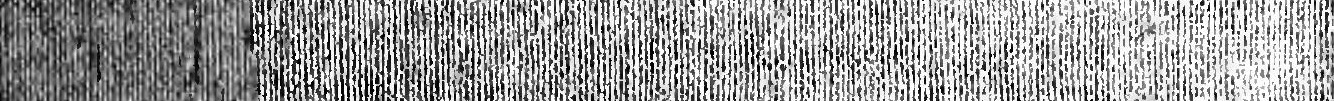

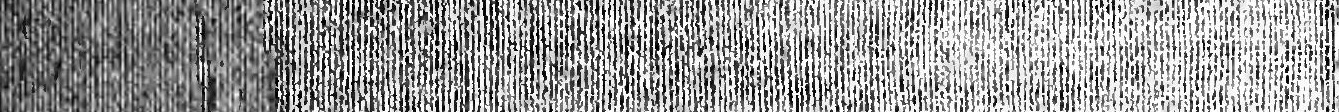
-2.

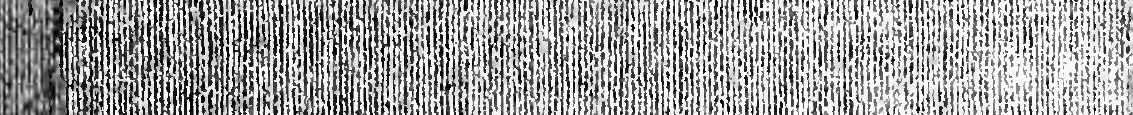








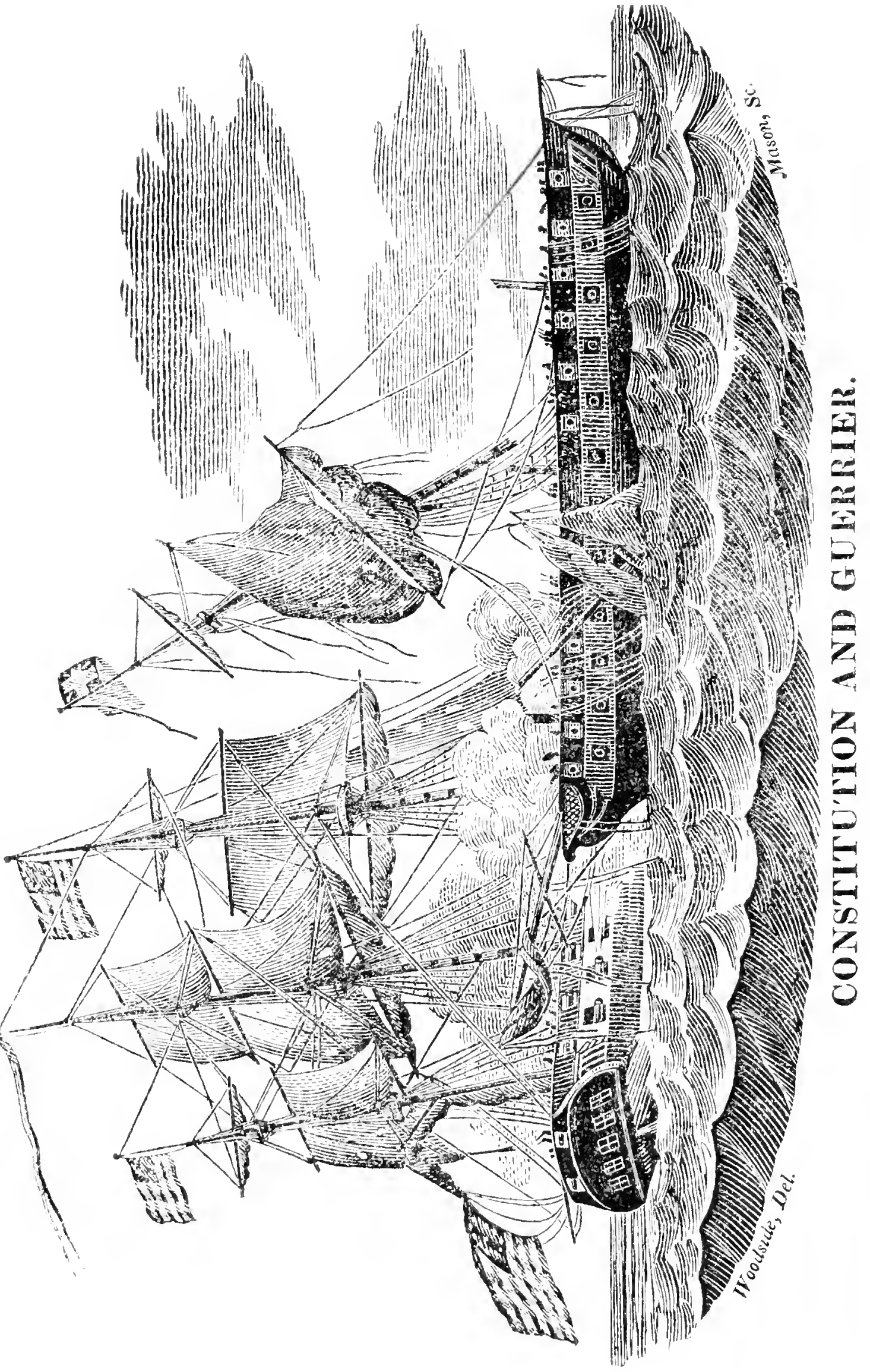




\title{
CONSTITUTION AND GUERRIERE.
}

\section{Challenge of Captain Dacres.}

\author{
Mrashingion City, October 30, 1812.
}

Correct Copy of Captain Dacre's Challenge, as enclorsed in his handwriting, on the register of the brig John Adams, arrived at New York, which register is now in this city.

"The Guerriere, 44 guns, and 500 men, will be happy to see the President, Commodore Rodgers, outside the Hook, or any other of the large Frigates, to have a sociable tete-a-tcte."

\section{Official Letter of Captain Hull.}

\section{United States' Frigate Constitution,}

Off Boston Light, Aug. 30, 1812.

SIR-I have the honour to inform you, that on the 19 th instant, at 2 P. M. being in latitude 41 degrees 42 minutes, and lon 55 de grees 4.8 minutes, with the Constitution under my command, a sail was discovered from the mast head, bearing E. by S. or ESE; but at such a distance we could not tell what she was. All sail was instantly made in chase, and soon found we came up with her. At 3 P. M. could plainly see she was a ship on the starboard tack, under easy sail, close on the wind. At half past 3 P. M. made her out to be a frigate; continued the chase, until we were within about three miles, when I ordered the light sails taken in, the courses haled up, and the ship cleared for action. At this time the chase had backed her main topsail, waiting for us to come down. As soon as the Constitution was ready for action, I bore down with an intention to bring him to close action immediatcly; but on our coming within gunshot, she grave us a broadside and filled away, and wore, giving us a broadside on the other tack, but without effect, her shot falling short. She continued wearing and manouvering for about three quarters of an hour, to get a raking position, but finding she coud not, she bore up and run unm der her topsails and jib, with the wind on the guarter. I immediately made sail to bring the ship up with her, and five minutes before sis, P. M., being along side, within half pistol shot, we commenced a heavy fire from all our guns, double shotted with round and prape; and so well directed werc they, and so warmly kept up, that in fifteen minutes his mizen mast went by the board and his main yard in the slings, and the hull, rigging and sails very much torn to pieces. The fire was kept up with equal warmth for fifteen minutes longer, when his main mast and fore mast went, taking with then every spar exeept the bowsprit. On seeing this, we ceased firing; so that in thirty minutes after we sot fairly along side the enemy, she strrendered, 
and had not a spar standing, and her hull below and above water se shatered that a few more brodelsides must have carried her down.

After informing you that so line a ship as the Gurrorere,com. manded by an able and experienced oflicer, had been totally dismasted and ot iciwise cut to picces, so as to make her not worth towing into port, in the short space of thirty minutes, you can have no doubt ol the gallantry and good conduct of the officers and ship's company I have the honour to command. It only remains therefore for me to assure you, that they all fought with great bravery; and it gives me great pleasure to say, that from the smallest boy in the ship to the oldest seaman not a look of fear was scen. They all went into acion, giving three cheers, and requesling to be laid close along side the enemy.

Iuclosed, I have the lionour to send you a list of killed and wounded on board the constitution, and a report of the damages she has sustained; also a list of the killed and wounder on board the enemy, with his (frarter bill. Sc. I have tise honour to be, with very great respect, Sir, your obelient servant,

IIon. J'aul Ilamilton, Sceretary of the Niry.

ISAAC HULL.

\section{Return of Filled and Hinunded on Loard the United States' frigats \\ Constubtion, Isace Ihall, esq. Caflain, in the action guith H. M. shifh \\ Gurvire, James R. Dacres, estr. Captuin, on the 19th Aug. 1812. \\ Liblen-Willian S. Bush,* first lieutenant of marines; Jacob Sigo, scaman; Robert Bice, ditto; John Brown, ditto; Janıcs Read. ditce; Caleb Smith, dito; James Ashford, ditto.}

* 'Tribute of frespect.-At a mecting of the young men of the Boluugh of

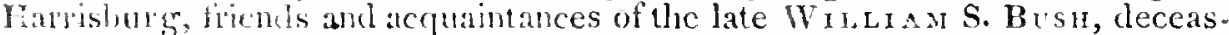
cl, lient. Johm Machesncy was called to the chair, and G. W. Hollis appointed seeretry, ater which the following preamble and resolutions were unamimotisty ackelued:

It hireas, lle gorcmment of the United States haring been compelled, by the injustice of ileat Britain, to assert at the cannon's mouth the rank she hotls among the nations of the earth, has made a stand worthy of an indepen. lient people, and can proudly boast that thousands of her brive sons havo voluntered in ler service, and are wiling to risk their "lives, their fortunes, and ibeir sicled lomours, in lier just defence.

Anomg lle first of these was licutenant Milliam S. Bush, of the United "tides' Marimes, who wa killed on the 19th ult. in the glorious contest between lla libiled States' fighate Constitution, Captain Huli, and the British frigate

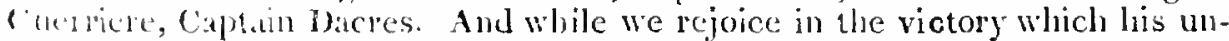
finduaste destimy denied him to share, we deplore the loss of so brave an offico', whese vilines were only coualled b" his valour and patriotism. Ile fell an raly rictim in his country's cause, and sacrificed a life dear to all who knew linis, in deferce of injured inverica.

Firevefore, as at testinom of the ligh estimation in which we held the dejated hero, and as a tribuic ol pespect to his memory,

Itriseral, that the members of this meeting wear crape on the left arm dur. ing inirly diags.

Bublict, Plut the Rev. Mr. Gloninger be requested to deliver a discourse sited wo the occasion, and that this mecting form a procession on tomorrow, aliti attend divine morship.

Ii) older of the mencetings,

JOHN MECHFSNEY, chairman.

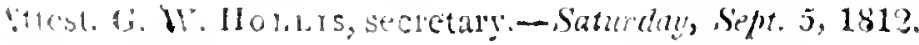


WoundeD-Charles Morris, first lieutenant,* dangerously; Johr C. Aylwin, master, slightly; Richard Dunn, seaman, dingerously; George Reynolds, ordinary seaman, dangerously; Daniel Lewis, ditto, ditto; Owen Taylor, ditto, ditto; Francis Mullen, marine, slightly.

Recafitulation-Killed, one lieutenant of marines, and six seamen; total killed, seven.-Wounded, two officer's, four seamed, and one marine; total wounded, seven.

Total killed and wounded, fourteen.

ISA AC HULL, Captin

T. J. CHEW, Purser.

Enited States' frigate Constitution, August 21, 1812.

\section{Lisi of the killed and Wounded on board the Guervicre.}

WoundeD-James R. Dacres, captain; Bartholomew Kent, lieut.; Samuel Grant, master's mate; James Emslie, midshipman; 'T. Harrington, armourer; Wm. Mee, arm. mate; Patrick Murphy, quarter gunner; J. Cromwell, quurter master; and fifty three seamen, ordinary seamen and marines-total wounderl, 61.

KiLLED-H. Ready, second lieutenant; J. Smith, second gunner's mate; G. Griffiths, quarter gunner; J. A. Fox, serje:nt of mirines; and eleven seamen, ordinary seamen, and marines.-Total killed, 15.

Missing-Twenty four.

Total killed, wounded, and missing, -101 .

At a stated meeting" of the "Democratic Young Men of the City and iberties of Philadelphia,' held on Saturday evening, 5th September, the following resalutions were unanimously adopted.

Resolzed, 'That we express our high approbation of the gallant conduct of Captain HuL , his officers and crew, in defeating the British tirigatc Giveriere, -and we wish them health and long life for the good of America.

Resolved, That each rnenber of this association wear erape on his left arm for one month, as a token of regret at the death of Lientenant Busu and his brave companions, who fell deferding the flag of their country.

A. PElRLEE, sccretary.

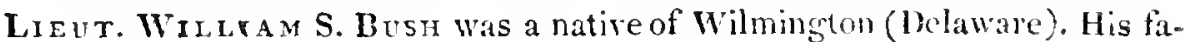
ther, Captain John Bush, was a meritorious officer in the revolutionary war, and he was the nephew of the brave Major Lewis Bush, who fell supporting the canse of his country at the battle of Brandywine.

* Now Captais Morris-haring been promoted since to the command of the frigate. Allems, of thirly two guns. Captain Norris has erer been distinguishcd in the nary for his unremitted application in the acquirement of natutical information; for activity, intelligence, and zeal in the finthful discharge of his duty. His gallant conduct, while under Commodore P'reble, in the Trijo. litan war, gained lim the confidence of his commander, the admiration of his companions in arms, and the applauses of his countrymen. He was the first man who gained the deck of the frigate Philadelphia, on that ever memorable night, when, under the batteries of the enemy, she was wrapt in flames by the Spartan band, under lieutenunt Decature; for which brilliant exploit the Pres sident most justly grave the latter a captain's commission. When the Co:stitation made her egsape from the British squadron off the Capes of the Chesapuake - o licut. Morris did the magnaninous Hull gire nuch of the ereditas: quired in that masterly retreat. Those who personally know the stering north ind intrinsic merit of Captain Morros, cannot but rejoice that his manly wive tues and naval talents have now a more ample field of exertion in his country

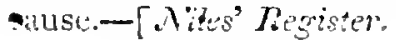


Prarncuiars of the Acton between the U. S. Frigate Constitution, and the British Frigate Guerriere. Communicuted to the edilors of the Boston Gazette, by an Officer on board the Constitution.

Lat. 4.1, 42, N. lon. 55, 48, W. Thursday, Aug. 19, fresh breeze from N. W. and cloudy, at a P. M. discovered a vessel to the southward, made all sail in cliase; at $s$, pcrceived the chase to be a ship on the starboard tack, close haled to the wind; haled S. S. W.; at half past 3 , made out the chase to be a frigate; at 4, coming up with the chase very fast; at quarter before 5 , the chase laid her main topsail to the naast; took in our topgallant sails, stay-sails, and flying gib; took a second reef in the topsails, haled the courses up; sent the royal yarcls down; and got all clear for action; beat to quarters, on which the crew gave three cheers. At 5 the chase hoisted three En. glish ensigns; at 5 minutes past 5 , the enemy commenced firing; at 20 minutes past 5 , set our colors, onc at each mast hearl, and one at the mizen peals, and began firing on the enemy, and continued to fire occasionally, he wearing very often, and we mancuvering to close with him, and aroid being raked; at 6 , set the main topgallant sail, the enemy having bore up; at five minutes past 6 , brought the enemy to close action, standing belore the wind; at 15 minutes past 6 , the enemy's mizen mast fell over on the starboard side; at $20 \mathrm{~min}-$ utes past 6 , finding we were drawing ahead of the enemy, luffed short round his bows, to rake him; at 25 minutes past 6 , the enemy fell on board of us, his bowsprit foul of our mizen rigging. We prepared to board, but immediately after, his fore and main mast went by the board, and it was deenied unnecessary. Our cabin had taken fire from his guns; but soon extinguished, without material injury. At $30 \mathrm{~min}$ utes past 6 , shot ahead of the enemy, when the firing ceased, on both sides; he making the signal of submission, by firing a gum to leeward. Set foresail and mainsail, and lraled to the eastward to repair da. mages: all our braces and much of our standing and ruming rigging and some of our spars being shot away. $A t 7$, wore ship, and stood uncier the lee of the prizc-sent our boat on board which returned at 8 with Capt. Dacres, late of his majesty's ship Guerriere, mounting 19 carriage guns, and manned with 302 men: got our boats out, and liept them employed in removing the prisoners and baggage from the prize to our own ship. Sent a surgeon's mate to assist in attending the wounded, wearing ship occasionally to kcep in the best position to receive the boats. At 20 mintites before 2, A. M. discorered a sail off the iarboard beam, standing to the south-saw all clear for another action; at 3 the sail stood off again. At daylight was baited by the lieut. on board the prize, who informed, he had 4 feet of water in the hold, and that she was in a sinking condition: all hands employed in removing the prisoners, and reparing our own damages through the remainder of the day. Fridlay the 20 th commenced with light breczes from the northward, and pleasant; our boats and crew stil! cmployed as belore. At 3 P. M. made the signal of recal for our bouts, (having received all the prisoners); they immediately left her an fire, and a guarter past 3 , slic blew up. 


\section{From the Londion Gazette.}

Admiralty Office, Oct. 10, 1812.

Copy of a Letter from Vice Admiral Sawyer to John William Crgker, escy. dated on board His Majesty's ship Alrica, at Halifix, the 15 th of September, 1812.

SIR-It is with extreme concern I have to request you will be pleased to lay before the Lords Commissioners of the Admiralty, the enclosed copy of a letter from Captain Dacres, of his Majesty's late ship Guevriere, giving an account of his having sustained a close action of near two hours, on the 19 th ultimo, with the American frigate the Constizution of very superior force, bcth in guns and men, (of the latter almost double) when the Gucrriere, being totally dismasted, she rolled so deep as to render all further efforts at the guns unavailing; and it became a duty to spare the lives of the remaining palt of he: valuable crew, by haling down her colours. The masts fell over the side from which she was about to be engaged, in a very lavourabie position for raking the enemy. A few hours after she was in posses. sion of the enemy, it was fonnd inmossible to keep her above water; she was therefore set fire to and abandoned, which I hope will satisfy their lordships she was defended to the last.

I have the honour to be Sc.

(Signed)

H. SAIVYER, rice admira!:

\section{Official Letter of Captain Dacres.}

Boston, Sefit.7, 1812.

SIR-I am sorry to inform you of the capture of His Miljesty's late ship Guerriere, by the American frigate Constitution, after a severe action, on the 19 th August, in lat. 40 degrees 20 minutes north, and long. 55 degrees west. At 2 P. M. being by the wind on the starboard tack, we saw a sail on our weather beam, bearing down on us. At 3 , made her out to be a man of war, beat to quarter's and prepared for action. At 4 , she closed fast, - wore to prevent her raking us. At 10 minutes past 4 , hoisted our colour's and fired several shot at her. At 20 minutes past 4 she hoisted her colours and returned our fire; wore several times to avoid being raked, exchanging broadsides. At 5 she closed on our starboard beam, both keeping up a heavy fire, and stecring free; his intention being evidently to cross our bow. At 20 minutes past 5 our mizen mast went over the starboard quarter, and brought the ship up in the wind: the enemy then placed himself on our larboard bow, -raking us, - a few only of our bow guns bearing; and his grape and rificmen sweeping our deck. At 40 minutes past 5, the ship not answering her helm, he attempted to lay us on board; at this time Mr. Grant, who commanded the forecistle, was carried below, badly wounded. I immediately ordered the marines and boarders from the main deck: the master was at this time wounded through the knee, and I received a severe wound in the back. Lieut. King was leading on the boarders, when the ship coming to, we brought some of our out bow guns to bear on her, and had got clear of our opponent, when at 20 minutes past six our fore and main masts went over the side, leaving the ship a perfectly unmanageable wreck. The frigate 
shooting ahead, I was in hopes to clear the wreck and get the she under command to renew the action; but, just as we had clearcal the wreck, our spritsail yard went: and, the enemy having rove new braces, \&c. wore round within pistol shot, to rake us:- the ship lying in the trough of the sea, and rolling her main deck guns under water, and all attempts to get he: before the wind being fruitless; when calling my few remaining officer's together, they were all of opinion that any further resistance would only be a ncedless waste of lives, I or. dered, though reluctantly, the colours to be struck.

The loss of the sbip is to be ascribed to the carly fall of the mizen mast, which enabled our opponent to choose his position. I am sorry to say we suffercd severely in killed and wounded, and mostly while she lay on our bow, from her grape and musketry: in all 15 killed and 63 wounded, many of them severely. None of the wounded officers quitted the deck till the firing ceased.

The frigate proved to be the United States' ship Cons'itution, of 20 twenty-four pounders on her main deck, and 24 thirty-two pounders and two eighteens on her upper deck, and 4.76 men. Her loss, in comparison witls ou!s is uifling, about 20: the first lieutcnant of marines and 8 killed, and first licutenant and master of the ship anc? 11 wounded. Her lower masts badly wounded, and stern much shat tered, and very much cut up about the rigung.

The Guerrice was so cut up, that all attempts to get her in would have been useless. As soon as the wounded were got out of her, they set her on fire; and I feel it my duty to state. that the conduct of Cap. tain Hall and his officers to our men has been that of a brave enerny; the greatest cure being taken to prevent our men losing the smallest trifle, and the greatest attention being paid to the wounded.

[H,re Captain Dacres particularizes the conduct of his officers, to whom and "the ship's compuly, he says, the grcatest credit is duc for their exertions, particularly when exposed to the heavy raking fire ol the enemy."] He then goeson-.

I hope, in considering the circumstances, you will think the ship entrusted to my charge was properly defended. The unfortunate loss of our masts, the absence of the third lieutenant, second lieutenant of mariucs, three midshipmen, and twenty four men, considerably weakened our crew, and we only mustered at gutarters two hundred and forty-four men, and ninetecn boys, on conning into action-the enemy had such an advantage from his marines and rifemen, when close, and his superior sailing clabled him to choose his distance.

I inclose herewith a tist of the killed. and wounded on board the Guerrice, and have the honous to be, sce.

\section{JAS. R. DACRES.*}

1 list of Officess, Seamen, and Marines killed and wounded on bourä his majesty's whit Gierricere, in the action of the 19th .1ug 1812.

KuLAb-IIenry Realy, second lieut., and fourteen scanen.

Wouxdid-James Rd. Dacres, esqr. captain, severely; Bartholo. mew Kert, first liencuan, slimhly; and sixty onc seamen.

" (aprain l) ACREs is a son of lhe late Admiral Dacres, and was made Po... (a)tatin in 1806. 
Extract from the Log Book of an Officer, who was on board hes majesty's shith the Guerriere, in the Action suith the Constitution.

" His majesty's ship Guerriere, being on her return from a cluise, her foremast and bowsprit crippled, and most of her fore rigging gone-on the 19 th of August, lat. 40, 20, N. and long. 55, W. at 2 o'clock, P. M. saw a sail on weather bean, coming down before the wind-made sail in chase. At 3 P. M. made her out to be a man of war-went to qualters and cleared for action-at 4. o'clock the cinase was discovered to te the United States frigate Constitution, which we had formerly chased off New-York; but which had escaped by superior sailing, from the Englisls squadron. Haled up the cour. ses, took in the topgallant sails, backed the main topsail, and hoisted an ensign at each mast head. The enemy shortened sail and haled to the wind. Filled our main topsail. At 4 hours 15 minutes the Constitution bore up and hoisted her coloms at each mast head. Fired a shot over him; and finding it to go about half a mile beyond him, gave him our starboard broadside, and wore to give him our larboard. At 4 hours 20 minutes the enemy commenced firing; wore several times, to aroid being raked, exchanging broadsides. At 5 hours our opponent closed within balf pistol shot on our starboard beam, both steering free and keeping up a heavy fire. At 5 hours $20 \mathrm{~min}$. utes, the mizen mast was shot away, fell over cur starboard quarter, and brought the ship up in the wind, against her helm, which exposed us to a heavy laking fire from the enemy, who placed himself on our larboard bow: a few only of our bow guns could be brought to bear on him; whilst his grape shot, and rifemen in his tops, were sweepingr our decks. At 5 hours 40 minutes, the ship not answering her.helm, he attempted to cross our bows and lay us on board. At 5 hours 55 minutes, our bowsprit got foul of his larboard quarter. Got the bourders up to board him; but the sea rumning too high it was found to be impracticable. Both ships keeping up a fire with musketry, and we with the bow gun, the only one that would bear. At this time most of our men on the quarter deck and the forecasde were picked off by his musketry. At 6 hours 26 minutes the ship coming to, we brought some of the bow guns to bear on him, and got clear of the enemy. The fore and main masts then went over the starboard side, and completely disabled our guns. The constitution immediately made sail ahead, leaving the Guerriere an unmanageable wreck. All hands were immediately employed in clearing the wreck, in hopes of being able to get the ship before the wind to recommence the action; but just as we had completed clearing her, the spritsail yard went away, and left the ship in the trough of the sca, rolling her main deck guns under water. Our opponent, by this time, had refited and wore round to rake us; and all attempts to get the ship before the wind, or to bring any of our guns to bear, proving in vain-. -the ship in a sinking condition-much shattered in her hull, ininy shot between wind and water, onc third of her crew killed and wounded, Capt. Dacres called his remaining oricers together-when all were of opinion, that any further resistance would be a useles; expense of lives. At 6 hour's 45 mimutes the juck was taken from the stump of the mizen mast 
The Guerriere was a frigate of 1084 tons burthen, taken from the French in 1806, and had 302 men and boys belonging to her; but the $3 \mathrm{~d}$ lieut. $2 \mathrm{~d}$ of marines, 3 midshipmen and $24 \mathrm{men}$, were away in prizes; there were ten American seamen on board, who had belonged to her for some years; but as the declaration of war against Great Britian was not known when she sailed, there had been no opportunity of discharging them; and Captain Dacres considering it as unjust to compel a native of the United States to fight against his countrymen, granted them permission to quit their quarters and go belowso that we had only actually in action $244 \mathrm{men}$ and 39 boys.

\section{"Incongruities."}

In the Ialifax account of the Guerriere's misfortune, the writer eriticises the "incongruities" of captain Hull. The real object, howcver, of his communication, is, to introduce an insinuation that the zuerriere was crippled in her foremast and bowsprit, and most of her fore rigging gone." He is as unfortunate in his apology, as he is in his criticism. For it cannot be believed that the Guerriere, the fighting Guerriere, ${ }^{*}$ was cruising with "her fore rigging gone." Inreed the neglect to rcplace it would be more difficult to account for than the loss of his ship: And her "crippled" bozwsfirit was the only spar that survived the action. Had he told us his mizen-mast was "crippled," it would have done much better.

We surely ought not to expect " incongruities" from this gentleman, and yet, from a "crippled mast" we are told of his taking in copsallant sails; that 'the sea was running so high as to be impracticable to board him' and that the ship (shortly after) was 'rolling her main cleck guns under water.'

It was an abortive effort to swagger, when he tells us of having " made sail in chase," and that "the chase was discovered to be the United States frigate Constitution, which he had formerly chased off New York, but which escaped us by suferior sailing." The indulgrence of this propensity was very unfortunate to precele the story of having overhaled her, as he makes it out, in a "chase" of less than iwo hours, and with "crippled" spars. This, however, is only an "incongruity."

He has made one attempt more to rally, in extending the time of the close action, which Captain Hull states to have been 30 minutes; hut one would be somewhat at a loss, whether by this he meant to compliment the gallantry of the victor or the vanquished. The Guerrere, he ades, " lay an mumanageable wreck,' ' in a sinking condition,' many shot between wind and water, with ore third of her crew kill. ad id woumled.' The Constitution speaks for herself-five shots in her hull. let the time, however, bave been the one or the other, we think the Guerriere, if her loremast had be en crippled. ought to hro ogged away at litule with her guns.-- [A: York Cohmonon.

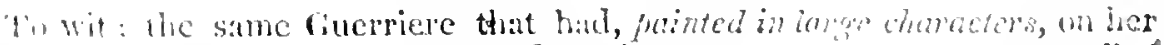

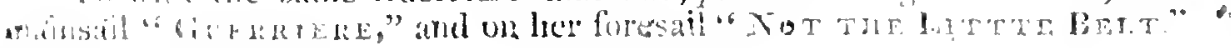




\title{
Size of the Guerrier and Constitution.
}

The size of the Guerrier having been variously reported, we publish the following letter of Captain Lavie, commander of the Blanche, to Lord Keith.-[Boston Cent.

\section{CAPTAIN LAVIE TO LORD KEITH.}

\section{"Blanch, Yarmouth, July 26th, 1806.}

"MY Lor D-I have the honour to acquaint you of my return to Yarmouth to-day, having in company the Guerrier frigate, commanded by Monsieur Hubert, of the Icgion of honour, whom I captured on the 19 th inst. in longitude 62 , off the Faro islands, after a short contest of 45 minutes.

"Le Guerrier is of the largest class of frigates, mounting fifty guns, with a complement of $317 \mathrm{men}$, but they were very soon sadly reduced by our destructive fire, and the ship has also suffered very severely, while the damages of the Blanche were confined to the topmasts, rigging and sails.

THOMAS LAVIE."

The following Certificate was before the Naval Committee of Congress.

"We were on board the Africa from the 11th of July to the 26th of August, during which time we frequently saw the Guerrier, captain Dacres, and we certify that we frequently counted the guns of that frigate, and that she mounted on her main battery, thirty guns-on her quarter-deck sixteen 32 pound carronades, and on her forecastle eight guns-making an armament of fifty-four guns.

EDWARD GRANWELL,

WILLIA Y H. CHAILLE,

Washington, Nov 2, 1812. Midshipmen late of the Nautilus.

The Constirution rates 44 guns and mounts 55 ; her complement of men is 450 . Her gun-deck guns are 24 pounders, her carronades 32 pounders.

The quantity of ammunition expended by the Constitution in the action with the Guerrier, viz. - 300 241b. shol-230 32lb. shot-10 $18 \mathrm{lb}$ shot-140 32lb. grape-12024lb. grape-4024ib. cannister$60321 \mathrm{~b}$. cannister-40 $241 \mathrm{lb}$. double headed-2376lbs. gun powder.

\section{Dimner in honor of Captain Hull at Boston.}

\author{
[FRON THE DOSTON CHRONICLE.]
}

On Saturday last, September 5 , in pursuance to previous arrangements, a public entertainment at Fanetil Hall was given to $\mathrm{C}_{A}$ prain HLLL, in celebration of the late brilliant achievement of the Constitution frigatc. An unusual assembly of the citisens, amounting to nearly six hundred, without the least distiction of party, were present 
on the occasion. Among the distinguished guests, were the officers of Commodore Rodger's squadlon [the Commodore, we reglet to state, was 00 much incisposed to attend], Brigadicr General Boyd and staff judise Peitson, ol It. Yolk, and many grentemen from the southward.

It an early hour in the mornines, State-street, and the way in con tinustion quite down to the end of Long wharf, off which the squad. ron was lying at anchol, was beautifully decorated by a display of fargs, lrom the tops and windows of the buildings on both sicles, and from the masts of vessels.

At 30 clock the prucession was formed at the Fxchange coffee inuse, and went from thence, preceded by an excellent band of rullsic, to the h.ll of cntertainment. The hon. John C. Jones, presidevt of the day, with Cupain Hull on his right, and immediately folluwed by sis ricepresidents, formed the head of the procession on its wy to the hall. The concourse of citizens in the streets induh micis the procession moved, now withstanding the unpleasant welness of the dat was larger than we have witnessed on almost any wher occasion. They gave tiree cheers as the procession passed down btate-strect. The decorations of the hall, which were conducted by colmel Homy Sugeant, were in the highest degree brilliant and appropriatc. Indeed all the arrangements of the day were splendid and elegant, and such as do great credit to the committees by whom they were superintencted. It is with the greatest satisfaction ve can ard thit not an incident occurred in the course of this day which could hare been ofiensive to the feelings of any individual. So large and respectable a convention of citizens of different political sentiments, haring lud aside their enmities, and mingled togcther indiscriminaty in celebration of an achievement so honourable to iteir country, was indeed a novel and most interesting spectacle; and it is in the highest derree honourable to the town of Boston, that on one occasion at least the emotions of patriotism have had a complete ascendancy and triumph orer frarty contention and prejudice.

The following are the toasts given on the occasion:

1. The Anerican . Vation-May danger from abroad ensure unioi st hone.

2. The President of the United States.

$\therefore$ The Gorernor of this Commonwealth.

4. Our infont . Vity-IVe must nurture the young Hercules in his cranle, if we would profit by the hahours of his manhood.

5. The Tictory we celebrate-An invaluable proof that we are able to defend nur rishts on the ocein.

6. A specty peace with the country of our ancestors; and until that event. a contest so conducted as not to banish the recollection of past. or the hope of future friendship.

7. No entangling Alliances-TVe have suffered the injulies and insults of despotism with patience, but its friendship is more than we can hcar.

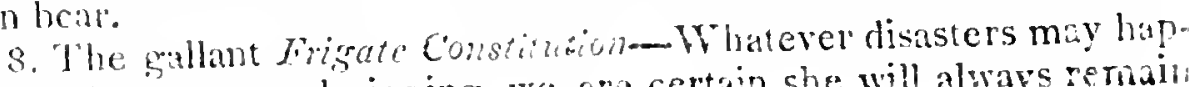
pen to her spars and rigring, we are certain she will always remain sifte and eound in her limit. 
¿The honorabie president then proposed the folluwing sentiment-

"The Memory of the gallant Bush - Our tear's like our joys come from the heart.']

9. The Fourth Regiment of Infuntry. The valur and discipline which saved our army from the fury of savages are crowned with laurels, which misfortune cannot wither.

10. The Officers and Crewes of our little fleet.-A galaxy of talent and courage-Let their country afford the means and occasion, and they will requite their country by victory and honoul.

11. Freedom to our Commerce-It asks thousands for ciefence, and would give millions for revenue.

12. The wemory of our country's father-May his spinit inspire our councils in war and in peace.

13. The American Eugle-Instead of wasting her lightnings on the desert, may they be reserved for a nobler conflict on the deep.

14. A Free Press-The natural source of those rights of which a navy is the surest defence.

15. Our Autional Union-Strict fidelity to the nation in every state, and equal protection in the interests of every state by the power of the nation.

16. The Memory of Commodore Prente-A peerage and a statue rewarded the hero of Trafalgar-May the hero of Tipoli find a title and a monument in the imperishable gratitude of his country.

17. Russia, Spain and Portugal-The patriots of all nations, who are engaged in the defence of the rights of mankind.

\section{Honour to the Brare.}

[From the New York Gize: te of September 9.]

At a meeting of the Common Council yesterday, the following re. solution, brought forward by Mr. Laurence and seconded by Mr. AlGerman Bucknaster, unanimously passed the board.

"The Common Council of the city of New York, considering a daval establishment all-important to the protection of our culniry. and viewing the recent capture of the British frigate Guemer by the American frigate Constitution, as not only illustrating the advaintages of a navy, but as reflecting the brightest honour on the intrepirlity and skill of Captain HuLL, his officers and crew, esteem it thcir duty as the municipal government of this great commercial city, to express their sentiments on this occasion, and to present the thanks of the citizens of New York to the gallant officers, and seamen who achieved this splendid victory.

"Resolved, "That the FreEDom of the city be presented to Captain HULL in a gold box, with an appropriate inscription, and that his honour the Mayor be requested to forward the same, with a copy of this resolution."

At a meeting of the citizens of Philadclphia, held at the Rerchant's Coffee House, Saturday, September 5ih, 1812, for the purpese of devising an appropriate expression of the sense they entertain of the witlant conduct of Captain JsaAc HuLr, and the officess and crew of the 
United States' frigate Constituiton, in their engagement with his Britannic majesty's frigate Guerrier, Commodore Richard Dale was chosen chairman, and Joln Sergeant, secretary.

The following resolutions were read and unanimously adopted.

The brilliant victory which swells with pride and gratitude in every American bosom, is of a character to challenge the annals of naval fame for a parallel, and the more it is analyzed, the more will it exalt the glory of the heroes who achieved it. It is no less distinguished for the unexampled effects produced in less than half an hour, than for the cool, collected prowess and transcendant nautical tan $n$ int, which while dealing destruction to a brave, skilful and veteran foe, preserved the victor comparatively uninjured, and prepared again for battle and for conquest. Let this immortal record of fame animate the gallant defender's of our flag to similar cleeds of glory, and serve as an example of the high degrec of discipline and order to which a brave crew can be trained in the short space of three months, by the indefatigable zeal and skill of officcrs who are no les: an ornament to their prolession than to society.

Impelled by feelings flowing from a participation in the glory acquired for our country by the brilliant victory achicred by the commander, officers and crew of the United States' frigate Constitution. on the 19 th of August last, over the British frigate Gutrier, Captain Dacres,

Resolied, That a piece of plate of the most elegant workmanship, crnamented with appropriate cmblems, devices and inscriptions, be presented in the name of the citizens of Philadelphia, to Captain Is a AC HuL ; - and that a piece of plate also of the most elegant workmanship and ornamented with appropriate emblems, devices, and inscriptions, be presented in their name to licutenant Charles Morris, as testimonials of the respect and admiration the citizens entertain of thcir gallant conduct in the late action with the British frigate Guerrier; and that such tokens of their high esteem and approbation be presented to the other officers and to the crew of the frigate Constitution, as the committee to be appointed to carry this resolution into effect may deem proper.

Resolved, That Commodore Richard Dale, William Jones, George Harrison, Charles Biddle, Thomas IV. Francis, and John Sergeant, be a committee on behalf of the citizens, to carry the foregoing resolution into effect.

John Sergeant, Secretaly.

RICHARD DALE, Chairman. 



\title{
WASP AND FROLIC.
}

\section{Oficial Letter of Captain Jacob Jones.}

\author{
Coply of a letter from Captain Jones, late of the United States' slooh of \\ war the Wasti, to the Secretary of the Navy, dated
}

New York, 24th Norember, 1312.

SIR, - I here avail myself of the first opportunity of informing you of the occurrences of our cruise, which terminated in the capture of the $W$ asfi on the 18 th of October, by the Poictiers of seventy four guns, while a wreck, from damages received in an engagement with the British sloop of war Frolic, of twenty two guns, sixteen of them 32 lb. carronades, and four twelve pounders on the main deck, and two twelve pounders, carronades, on the top-gallant forecastle, making her superior in folce to us by four twelve pounders. 'The Frolic had struck to us, and was taken possession of about two hours before our surrendering to the Poictiers.

We had left the Delaware on the 13 th. The 15 th had a heavy gaile, in which we lost our jibboom and two men. Half past elevelt, on the night of the 17 th, in latitude 37 degrees north, and longitude 65 degrees west, we saw several sail, two of them appearing very large; we stood from them some time, then shortened sail, and steered the remainder of the night the course we had perceived them on. At daylight on Sunday the 18th, we saw them ahead-gave chase, and soon discovered them to be a convoy of six sail under the protection of a sloop of war; fcur of them large ships mounting from sixteen to eighteen guns. At 32 minutes past eleven, A. M. we engaged the sloop of war, having first received her fire, at the distance ol fifty or sixty yards, which space we gradually lessened until we laid her on board, aftel a well supported fire of 43 minutes; and although so near while loading the last broadside that our rammers were shoved against the sides of the enemy, our men exhibited the same alacrity which they had done during the whole of the action. They immediately sur. rendered upon our gaining their forecastle, so that no loss vas sustained on either side after boarding.

Our main topmast was shot away between 4 and 5 minutes from the commencement of the firing, and falling together with the main topsail yard across the larboard fore and fore topsail braces, rendered our head yards unmanageable the remainder of the action. At eight minutes the gaft and mizen topgallant mast came down, and at $20 \mathrm{mi}$ nutes from the beginning of the action every brace and most of the rigging was shot away. A few minutes after separating from the Frolic, both her masts fell upon deck; the mainmast going close by the deck, and the foremast twelve or fifteen feet above it.

The courage and exertions of the officers and crew fully answered roy expectations and wishes. Lieutenant Biddle's active conduct ron- 
tributed much to our success, by the exact attention paid to every de. partment during the engagement, and the animuting example he afforded the crew by his intrepidity. Lieutenants Rodgers, Booth, and Mr. Rapp, sliewed, by the incessant fire from their divisions, that they were not to be surpassed in resolution or skill. Mr. Knight, and every other officer, acted with a courage and promptitude inghly honorable, and I trust have given assurance that they may be relied on whenever their services may be required.

I could not ascertiin the exact loss of the enemy, as many of the dead lay buried under the masts and spars that had fillen upon deck, which two hours' exertion had not sufficiently removed. Mr. Biddle, who had charge of the Frolic, states, that from what he saw, and from information from the officers, the number of killed must have been abrut 30 , and that of the wounded atout 40 or 50 . Of the killed is her first lieutenant, and sailing master; of the wounded, Captain Whinyates and the second lieutenant.

We had 5 killed and 5 wounded, as per list: the wounded are re. covering. Lieut. Claxton, who was conlined by sickness, left his bed a little previous to the engagement; and though too indisposed to be at his division, remaineri upon deck, and shewed by his composed manner of noting its incidents, that we had lost by his illness the services of a brave officer. I am respectfully yours,

IIon. Paul Hamilton, Secretary of the Nary.

\section{JACOB JONES,*}

Iaving receired permission to copy the following account of the action between the WASP and FroLIC, we have taken the liberty to deviate in this instance from the plan we had adopted, of giving, in addition to the official letter of the commander, the letters of other officers of the ship. "The accuracy and the minuteness of this account supergede the use of those letters, which were introduced to strengtien and confirm that given by the commander, and to afford particulars of the action not communicated by him.

[FROM THE PORT FOLIO.]

American Gallantry. - Under this tille we have occasionally selectef such incidents in our military anmals, as, from their minuteness, hari escaped the view of the general historian; but which were calculated to excite the high and honourable feelings of patriotism. The present war has again awakened the encrgies of the nation; and al. ready produced examples of signal intrepidity among our country. men. It is, howerer, on the navy of the United States that our national pricle, and our hopes of grlory at this noment repose. We have nerer been able to lonk without the highest satisfaction on that fearless pro. fession, the nursely of grenerous courage, and of high-minded patriotism-10 whose followers cvery form of danger is alike familiar and without terror.

Nor toil, nor hazard, nor distress, appear

To sink the Seamen witb ummanly fear;

Who from the fitce of dinger strives to tum,

Indignant from the social hour they spurn;

No future ills, unknown, their souls appal,

They know no danger, or they scom it all.

- Captain JoNes is a mative of Kent county, state of Delaware 
Rut we have no language to convey our admiration of the young and gallant spirits, who, in the first essays of their strength, have triumphed over the veteran science, and the disciplined valour, of the habitual conquerors on the occan. They have retrieved all our disasters-they have shed new lustre on our arms, and sustained, even in the midst of mortifying reverses, the loftiest tone of national enthusiasm. Their only anxiety has been to find the enemies of their couniry; and, wherever they have met them, their valour has rendered victory certain, whilst their skill has made it easy.

Devoted, as is this journal, to all that can add honour or distinction to the national character, it has no fairer pages than those which record instances of bravery like the following, the account of which we have rendered scrupulously minute and authentic.

The United States' sloop of wal the W'ash, commanded by Captain $\mathrm{J}_{\Lambda \mathrm{COB}} \mathrm{J}_{\mathrm{N} \mathrm{N}} \mathrm{s}$, was cruising in long $65 \mathrm{deg}$. W. and lat. $37 \mathrm{deg}$. N., the track of vessels passing from Bermuda to Halifax, when, on Saturday, the 17 th of October, about cleven o'clock, in a clear moonlight evening, she found herself near five strange sail, steering eastward. As some of them seemed to be ships of war, it was thought better to get farther from them. The WVasp therefore haled her wind, and having reached a few miles to windward, so as to escape or fight as the occasion might require, followed the strange sail through the night. At diybreak, on Sunday morning, Captin Jones found that they were six larre merchant ships, under convoy of a sloop of war, which proved to be the Frolic, Captain Vhinyates, from Honduras to England, with a conroy, strongly armed and manned, having all forty or fifty men; and two of them mounting sistcen guns each. Hc determined, however, to attack them, and as there was a heavy swoll of the sea, and the weather boisterous, got down his topgallant vards, close reefed the topsails, and prepared for action. About eleven o'clock the Frolic showed Spanish colours; and the Wasp imnediately displayed the American ensign and pendant. At thirty-two minutes past eleven, the Wasp came down to windward, on her larboard side, within about sixty yards, and hailed. The enemy haled down the Spanish colours, hoisted the British ensign, and opened a fire of cannon and musketry. This the $\mathrm{W}$ asp instantly returned; and, coming nearer to the enemy, the action became close, and without intermission. In four or five minutes the main topmast of the Wasp was shot away, and, falling down with the main topsail yard across the larboard fore and fore topsail braces, lendered her head yarús unmanageable during the rest of the action. In two or three ninutes more her gaft and mizen topgallantsail were shot away. Still she continued a close and constant fire. The sea was so rough that the muzzels of the IVasp's guns were frequentiy in the water. The Americans, therefore, fired as the ship's side was going down, so that their shot went either on the encmy's deck or below it, while the English fired as the vessel rose, and thus her balls chiefly touched the rigging, or wcre thrown away. The Wasp now sliot ahead of the Frolic, raked her, and then resumed her position on her larboard bow. Her fire was now obviously attended with such success, and that of the Frolic so slack. ened, that Captain Jenes did lint wish to board her, lest the roughness 
of the ssa might endanger both ressels; but, in the course of a few minutes more, cvery brace of the Wasp was shot away, and her rigging so nuch torn to pieces, that he was alraid that his masts, being unsmpported, would go by the board, and the Frolic be able to escape. He thought, therefore, the best chance of securing her was to board, and decide the contest at once. With this view he wore ship, and, running down upon the enemy, the vessels struck each other, the Fasp's side rubbing along the Frolic's bow, so that her jibboom came in between the main and mizen rigging of the Wasp, directly over the herds of Captain Jones and the first lieutenant, Mr. Biddle, who were at that moment standing together near the capstan. The Frolic lay so fair for raking, that they decided not to board until they had given a closing broadside. Whilst they were loading for this, so near were the two vessels, that the ranmers of the Wasp were pushel against the Frolic's sides, and two of her guns went through the bow ports of the Frolic, and swept the whole length of her deck. At this moment, Jack Lans, * a scaman of the Wasp, a galiant fellow, who had been once impressed by a British man of war, jumped on a gun with his eutlass, and was springing on board the Frolic: Captain Jones, wishing to fire again before boarding; called him down, but his impetuosity could not be restrained, and he was already on the bowsprit of the Frolic, when, seeing the ardour and enthusiasm of the Wasp'screw, lieutenant Biddle mounted on the hammoc cloth toboard. At this signal the crew followed; but lieutenant Biddle's feet got entangled in the rigging of the enemy's bowsprit, and midshipman $\mathrm{Ba}$ ker, in his ardour to get on board, laying hold of his coat, he fell back on the WVasp's deck. He sprang up, and as the next swell of the sea brouglit the Frolic nearer, he got on her bowsprit, where Lang and auother seaman were already. He passed them on the forecastle, and was surprised at seeing not a single man alive on the Frolic's deck, except thc seaman at the wheel and three ofincers. The deck was slippery with blood, and strewed with the bodies of the clead. As he went forward, the Captain of the Frolic, with two cher officers, who were standing on the cuarter deck, threw down their swords, and made in inclination of their bodies, denoting that they had surrendered. At this moment the coluurs were still flying, as, probably, none of the scamen of the Frolic would dare to go into the rigging for fear of the muskctry of the Vasp. Lieutenant Biddle, the refore, jumped into the rigging himself, and hated down the British ensign, and possession was taken of the Irolic in forty three minutes after the first fire. She was in a shocking condition; the birth deck, particularly, was crowded with dead, and wounded, and dying; there being but a small proportion of the Frolic's crew who had escaped. Captain Jones instanly sent on board his surgeon's mate, and ali the blankets of the Frolic were brought from her slop roum for the comlort of the wounded. 'To increase this cotalision, both the Frolic's masts soon fell, covering the dead and crery thing on deck, and she lay a complete wreck.

It now appeared that the Irolic mounted sixteen $32 \mathrm{lb}$. carronades,

"John Lang is at mative of Aiew linumswick, in New Jersey. We mention, xith great picastre, the nume of his brave American seaman, as a proof that monspicuous vikur : contines? tho rank in the naval service. 
four 12 pounders on the main deck, and two 12lb. carronades. She was, therefore, supcrior to the IVasp, by exactly four twelve pounder's. The number of men on board, as stated by the officers of the Frolic, was one hundred and ten-the number of seamen on board the Wasp, was one hundred and two; but it could not be ascertained, whether in this one hundred and ten, were included marines and officers; for the Wasp had, besides her one hundred and two men, officer's and marines, making the whole crew about one hundred and thirty five.What is, however, decisive, as to thcir comparative force is, that the officers of the Frolic acknowledged that they had as many men as they knew what to do with, and, in fact, the WVasp could have spared fifteen men. There was, therefore, on the most favourable view, at Ieast an equality of men, and an inequality of four guns. The disparity of loss was much greater. The exact number of killed and wounded on board the Frolic could not be precisely determined; but from the observations of our officers, and the declarations of those of the Frolic, the number could not be less than about thirty killed, including two officers, and of the wounded between forty and fifty; the captain and second lieutenant being of the number. The Wasp had five men killed, and five slightly wounded.

All hands were now employed in clearing the deck, burying the dead, and taking care of the wounded, when Captain Jones sent orders to lieutenant Biddle to procecd to Charleston, or any southern port of the United States; and, as there was a suspicious sail to windward, the Wasp would continue her cruise. The ships then parted. The suspicious sail was now coming down very fast. At first it was supposed that she was one of the convoy, who had all fled during the engagement, and who now came for the purpose of attacking the prize. The guns of the Frolic were, therefore, loaded, and the ship cleared for action; but the enemy, as she advanced, proved to be a seventy-fourthe Poictiers, Captain Beresford. She fired a shot over the Frolic; passed loer; overtook the IVasp, the disabled state of whose rigging prevented her from escaping; and then returned to the Froilc, who could, of course, make no resistance. The Wasp and Frolic were carried into Bermuda.

It is not the least praise due to Captain Jones, that his account of this gallant action. is perfectly modest and unostentatious. On his own share in the capture, it is unnecessary to add any thing. "The conrage and exertions of the officers and crew" he observes, "fully answered my expectations and wishes. Lieutenant Biddle's active conduct contributed much to our success, by the exact attention paid to every department, during the engagement, and the animating example he afforded the crew by his intrepidity. Lientcnant Rodgers and Booth, and $\mathrm{Mr}$. Rapp, showed by the incessant fire from their divisions, that they were not to be surpassed in resolution or skill. Mr. Fnight, and every othel officer, acted with a courage and promptitude highly honourable. Lieutenant $\mathrm{Claxton}$, who was confined by sickness, left his bed a little previous to the engagement; and, though too weak to be at his division, remained upon deck, alad showed, by his composed manner of noting its incidents, that we had lost, by his illness, the services of a brave officer." 


\section{Official Letter of Captain Whinyates.}

[From the Iondon Gazette of December 26.]

Letter fiom Calitain Whinyates of the Frolic to Admival Warren.

H. M. Ship Poictiers, at sea, October 23.

SIR-It is with the most bitter sorrow and distress I have to re port to your cxcellency the capture of his majesty's brig Frolic by the ship Wast , belonging to the United States of A merica, on the 18 th inst.

$H_{\text {iaving }}$ under convoy the homeward bound trade from the Bay of Honduras, and being in lat. $36 \mathrm{deg}$. N. and $64 \mathrm{deg}$. W. on the night of the 17 th we were overtaken by a most violent gale of wind, in which the Frolic carried away ber main yard, lost her topsails and sprung the main topmast. On the morning of the 18th, as we were repairing the damages sustained in the storm, and reassembling the scattered ships, a suspiciaus ship came in sight, and gave chase to the convoy.

The melchant ships continued their voyage before the wind under all sail; the Frolic dropt astern, and hoisted Spanish colours, in order to decoy the stranger under her guns, and give time for the convoy to escape. About ten o'clock, both vessels being within hail, we haled to the wind and the battle began. The superior fire of our guns gave every reason to expect its speedy termination in our favour, but the gaft-liead braces being shot away, and there being no sail on the main mist, the brig became unmanageable, and the enemy succeeded in tak. ing a position to rake her, while she was unable to bring a gun to bear.

After lying sometime exposed to a most destructive fire, she fell with the bowsprit betwixt the enemy's main and mizen rigging, still unable to retuin his hre.

At length the enemy boarded, and made himself master of the brig, every individual officer being wounded, and the greater part of the men either killed or wounded; there not being twenty persons remaining unhurt.

Although I slall ever deplore the unhappy issue of this contest, it would be great injustice to the inerits of the officers and crew, if I failed to report that their bravery and coolness are deserving of every plaise; and I am convinced, if the Frolic luad not been crippled in the gale, I should have to make a very different report to your excellency. The Wasf was taken and Frolic recaptured the same afternoon, by his majesty's ship Poictiers. Being separated from them I cannot transmit at present a list of killed and wounded. Mr. Charles M'Kay, the first lientenant, and MIr. S ephens, the master, love died of their wounds. I have the honour to be, \&c. T. IVHINYATES.

\section{Jinner in honour of Captain Jones.}

Philadelphia, necember 12, 1812.

Carrar Jonfs, of the W $\mathrm{V}_{\mathrm{s}}$, arrived in this City, on the 9 th inst. uncier a handsome military escort by the volunteer troops of horse, and anid the loud plaudits of a great body of citizens who had assem. bled at the merchants' coffee-house to greet him as he passed. Yesterday a sfilcndill entertainment was given to him, at the City Hotel, in testimony of the high sense cutertained of his brilliant achievement 
in the capture of the British sloop of war the Frolic. The stewards of this honourable feast were Geo. Reinholdt, Hartman Kuhn, George Harrison, and Daniel W. Coxe, esqrs.

The company sat down about five o'clock to an elegant and well covered table, about 180 in number, and Irilliam Tilshinan, Chief Justice of this state, was called to the chair. His assistants were Edward Burd, esq., late prothonotary of the supreme court; Gen. John Burker, Mayor of this city; and Commodore Dale, the gallant first lieutenant of Paul Jones, in the war for independence. A band of instrumental music attended; and song and sentiment pervaded an evening in which the distinctions of party were overcome.

In the evening the company were attracted to the street, by a large procession, composed principally of masters of vessels, under the superintendence of Captain Stanley. An elegant transparent representation of American naval victories, supported by four captains, and a triumphal boat, decorated with various naval flags, drawn by citizens, and accompanied by hosts of shining lights, and an excellent band of music, exlibited a spectacle truly beautiful and interesting. The procession having halted, Captain Jones was conducted to the door, where he received the heartfelt and repeated acclamations of the people.

In front of the hotel was exhibited a finely executed transparency, representing the American naval pillar. It was surmounted by the American eagle, bearing a scroll, in which appeared, "Hcnour to the Brave." In the center the engagement between the Wasp and Frolic, with Captain Jones's name in glittering lines of fire below. The pedi ment was variously decorated, with the relative force of the two vessels, the time of the engagement-43 minutes- $8 \mathrm{cc}$.

Among the many toasts given on this occasion, the following volunteers were received with great enthusiasm:

Captain Jones, the gallant commander to whom we have this day offered a tribute of public respect.

Lieutenant Biddle and the other brave officers and crew of the Wast.

By the President-The people of the United States, amidst their rejoicings for the success of their arms, may they never forget that honourable peace is the noblest object of honourable war.

By Mr. G. Reinholdt-Captain Jones, may the liberality of his country soon enable him to take another Frolic.

By Col. Preston-Commodore Decatur. The man whom his native city delights to honour; he is an honour to his country, because he has vanquished his enemy both in valour and magnanimity.

By the Mayor-The Ocean, the gift of the Deity for the free use of his creatures.

By Samuel F. Bradford-The Memory of Lieutenant Bush-his spirit ascended amid the roar of cannon, the first herald to the skies of the naval glory of America.

By Ralph Izard, Esq.-The Memory of Lieutenant Funk, who gloriously fell in the late action between the frigates United States and Macedonian.

By Cafutain John Meany. The able bodied Seamen of the United States-they will never suffer any man to press them. 
By Mr. B. Hcury. Captain Chs. Stewart-May his Constellation. shine bright in the firmament of Amcrican glory.

By Doctor Cutbush. The Memory of Commodore Barry, under whom Decatur and Jones commenced their naval education.

By the Sheriff-Commodore Dale - who stood the roughest tus of war in the Bonne Homme Richard under Paul Jones.

By Arr. Samuel Relf-The Constitution Frigate, who retaliated on the Guerrier, the spots of the Leoflard.

By $M r$. Surgean-Captain Chauncey, who has carried farthest inland the naval glory of his country.

By D. Ir. Coxe-Oul Naral Commanders and their gallant Crews, the "never plead defective masts and want of preparation as an apo. ., for defeat.

\section{Tribute of Respect.}

Resolien, By the Senate and House of Represcntatives of the State of Deiatare in General Assembly met, That William H. Weils, Gcorge Read, jun., and Cornelius P. Comegys, be and they are hereby appointed a committee to convey the thanks of this General $A \mathrm{~s}$ sembly to J $J_{A}$ OB Jones, esqr, accompanied by an expression of the hich esteem in which they loold the biavery and skill displayed by himself, his officers, and crew, in the capture of the British sloop of war Frolic - a vessel much superior in force to the IVas 1 , commanded by him. And that the committee be directed to express the pricle and pleasure feit by this General Assembly in recognizing Captain Jones as a native citizen of the State of Delaware.

Resolied, That the said committee request Captain Jones to accept of a handsome piece of Plate, with appropriate emblematic engravings thercon, as a testimonial of the high estcem in which his services are hela by this General Assembly.

Resolved, That a sum not exceeding five hundred dollars be appropriated by law for the purchase of the said piece of Plate, to be paid on the draught of the said committee.

Nery-York, December 12.-Is Councir-The following resolution was presented to the Common Council, last evening, by Aldermin Lazirenre, and unanimously adopted:

Resolved. That an elegant Sworu be presented to Captain Jones, late of the United Statcs' sloop of war Ir 'resh, and also the Fredom of the City, as a testimony of the high opinion this Corporation entertain of his gallant conduct in capturing the British sloop of war Frolic, and that the thinks of the Common Conncil be presented to his brave officcrs and crew.

\section{Merit Rewarded.}

The following are the officers attached to the fiigatc Macedonian: Captaiu Jonfs; Lieutenants Rodgers. Carten, Booth, Claxton,

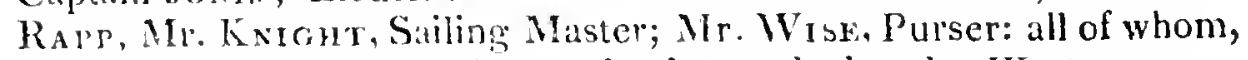
lieut nant Carter cxcepted, were lately attached to the $\|$ ras $/$.

Mr. BrDne, who so nobly distinguished himself in the action with the Frolic, is promoted to the rank of Master Commandant. 







\section{UNITED STATES AND MACEDONIAN.}

[From a London Paper of January 4.]

Frigatf. Macedonan.-This noble frigate, supposed to be the largest in the British navy, was lately refitted and repaired at Ply. mouth, and excited the admiration of prolessional men. Referring to the capture of the Guerrier, it has been often obserred, that if any British frigate could cope with the large American frigates that frigate was the Macedorias. She has 16 guns on her quarter deck alone-her metal is of an extraordinary weight-Captain Carden is one of the bravest officers in his Majesty's service, \&x. Sxc.

\section{Message of the President of the United States, communicating to Con- gress the Official Letters of Caftains Decaturand Jones.}

To the Senate and House of Representatives of the United States,

I transmit to Congress a copy of a letter to the Secretary of the Navy, from Captain Decatur, of the frigate United States, reporting his combat and capture of the British frigate Macedonian.

Too much praise cannot be bestowed on that officer and his companiors on board, for the consummate skill and conspicuous valour by which this troply hasbeen added to the naval arms of the United States.

I transmit also a letter* from Captain Jones, who commanded the sloop of war $H^{\top}$ as $/$, reporting his capture of the British sloop of was the Frolic after a close action, in which other brilliant titles will be seen to the public admiration and praise.

A nation, feeling what it owes to itself, and its citizens, could neve: abandon to arbitrary violence on the ocean, a class of men which gires such examples of capacity and courage, in defending their rights on that element; examples which ought to impress on the enemy, however brave and powerful, a preference of justice and peace to hostility against a country whose prosperous carecr may be accelerated, but cannot be prevented by the assaults made on it.

ITashington, Dec. $11,1812$.

JAMES MLADISON。

\section{Official Letter of Captain Decatur.}

U. S. Ship United States, at sea, Oct. 30, 1812,

The Hon. Paul Hamilton,

Sir -I have the honour to inform you, that on the 25 th inst. being in latiude 29 degrees $N$., longitude 29 degrees 30 minutes W., we fell in with, and, after an action of an hour and a half, captured his Britannic Majesty's ship Macedonian, commanded by Captain Joн N CAR。 DEN, and mounting 49 carriage guns, (the odd gun shifting). She is a frigate of the largest class, two years old, four months out of dock, and reputed one of the best sailers in the British service. The enemy

* Which see, ante p. 1;. 
being to windward had the advantage of engaging us at his own dis tance, which was so great, that for the first hall hour, we did not use our carronades, and at no moment was he within the complete effect of our musketry and grape-to this circumstance, and a heavy swell, which was on at the time, I ascribe the unusual length of the action.

The enthusiasm of every officer, seaman and marine on board this ship, on discovering the enemy-their steady conduct in battle, and precision of their fire, could not be surpassed. Where all met my fullest expectations, it would be unjust in me to discriminate. Permit me, however, to recommend to your particular notice, my first lieu. tenant $W^{\prime}$ lliam $H$. Allen. He has served with me upwards of five years, and to his unremitted exertions in disciplining the crew, is to be imputed the obvious superiority of our gunnery exhibited in the result of this contest.

Subjoined is a list of the killed and wounded on both sides. Our loss comparerl with that of the enemy, will appear small. Anongst our wounded you will observe the name of lieltenant Funk, who died a few hours after the action: he was an officer of great gallantry and promise, and the service has sustained a severe loss in his death.

The Macedonian lost her mizen mast, fore and main topmasts and main yard, and was much cut up in her hull. The damage sustained by this ship was not such as to render her return into port necessary; and had I not deemed it important that we should see our prize in, should have continned our cruise.

With the highest consideration and respect, I am sir, your obe dient humble servant,

(Signed)

STEPHEN DECATUR。

\section{Lis of killed and rounded on board the United States.}

Thomas Brown, N. Y., seaman; Henry Shepherd, Philadelphiz, ditto; William Murray, Boston, a boy; Michael O'Donnel, N. Y., private marine; John Roberts, do. do.-killed.

John Musser Funk,* Philadelphia, Lieutenant; John Archibald, $\uparrow$ N. Y., carpenter's crew; Clıristian Clark, ditto, seaman; George Christopher, ditto, ordinary seaman; George Mahar, do. do.; William James, do. do.; John Laton, do. private marine-zwounded.

On board the Macedonian there were thirty-six killed, and sixty.

* Since dearl-At a meeting of the young men of Lancaster, at the house of Mr. Slaymaker, in consequence of the death of Lieut. J. M. FuNk, a native of this bolough; captain Henry Shippen was called to the chair, and George L. Mayer, appointed secretary.

Whereas, with the deepest regret we have been apprized of the untimely death of our friend and fellow citizen, Lieutenant Jon M USSER Funk, who fell grloriously, fighting in the cause of his country, in the engagement between the frigate United States and the Macedonian, which ended in the brilliant vic. cory of the United States over the British frigate,

Resolvel, 'That, as a testimony of our' gricf at the loss of the companion of gur youth, our respect for his virtnes, and the high estimation in which we hold his memory, we will wear crape on the left alm for the space of thirty days.

6. L. MAYN, secretary.

H. SHILPEN, chairmin.

GENFROSITY OF A MEHICAN TARS.

+ Since dead.-The deceased left three children to the mercy of the world and worbluses mothar, who bud abinduned them. When his father went on 
eight wounded. Among the former were the boatswain, one master's mate, and the school-master; and of the latter were the first and third lieutenants, one master's mate, and two midshipmen.*

\title{
Official Letter of Captain Carden.
}

\author{
[From the London Gazette, January 1.]
}

Admiralty office, December 29, 1812.

Copy of a letter from Captain John Sulman Carden, late commander of his Majesty's ship the Macedonian, to John Wilson Croker, Esq.dated on bcard the American ship the United States, at sea, the 28th of October, 1812.

SIR-It is with the deepest regret I have to acquaint you, for the information of my Lords Commissioners of the Admiralty, that his Majesty's late ship the Macedonian was captured on the 25th instant; by the United States' ship United States, Commodore Decatur, commander, the detail as follows:-

A short time after daylight, steering $N$. W. by W. with the wind from the southward, in lat. $29 \mathrm{deg} . \mathrm{N}$. and long. $29 \mathrm{deg} .30 \mathrm{~min} . \mathrm{W}$. in the execution of their lordships' orders, a sail was seen on the lee beam, which I immediately stood for, and made her out to be a large frigate under American colours; at 9 o'clock I closed with her, and she commenced the action, which we returned, but from the enemy keeping two points off the wind, I was not enabled to get as close to her as I could have wished.

After an hour's action the enemy backed and came to the wind, and I was then enabled to bring her to close battle. In this situation I sonn found the enemy's force too superior to expect success, unless

board the frigate to claim the wages and property of his son, an inquiry into the circumstances of the family took place, and a plan was agreed upon by the seamen for the relief of the orphans, and two dollars a piece was immediately subscribed, amounting to about eight hundred dollars, for the maintenance and education of the bereaved infants, to be placed in the hands of suitable trustees.

Address of thanks. -The father of the deceased John. Archibald, who fell in the gallant action on board the frigate United States, under the command of the heroic commodore Stephen Decitur, avails himself of thus publicly return. ing his most sincere thanks to the Commander for his humanity and benevo. lence to him; and also to his gallant officers snd seamen (many of whom are personally acquainted with the deceased's father), for having contributed largely and honourably towards the support of the said deceased's three orphan children: which clearly demonstrates that the brare American seamen are pos. sessed both of courage and humanity superior to any other nation. May the same spirit that actuates the crew of the Lnited States animate others to the like gallant conduct; and the American flag will soon wave triumphantly by land and sea.

* Nerr London, Dec. 15.-Captain CARDEN speaks in the hichest terms of approbation of the conduct of Commodore DEcatur and his officers. All the private property of the officers and men on board the Macedonian was given up. That claimed by Captain Curden, (including a band of music and several casks of wine) valued at atrout 80 dollar's, the Commolore-whose soul is as liberal as brave-paid him for. Generosity could not have been more properly applied. Captain Carelen has been distingui jed for his civilities to such Ame. ricans as he met at sea before the war. His noble liberality and consoling attention to Captain Bolles and crew, of this place-who were driven from the coast last winter, and in danger of perishing-give him a tivle to all the resped and attention the requirements of war will a.mit. 
some very fortunate chance occurred in our farour, and with this hope $I$ continued the battle to two hours and ten minutes, when, having the mizen mast slot away by the board, topmasts shot away by the caps, main yard shot in pieces, lower masts badly wounded, lower rigging all cut to pieces, a small proportion only of the foresail left to the fore yard, all the guns on the quarter deck and forecastle disabled but two, and filled witis wreek, two also on the main deck disabled, and several shot between wind and water, a very great proportion of the crew killed and wounded, and the enemy comparatively in good oider, who had now shot ahead and was about to place himself in a raking position, without our being cnabled to return the fre,-being a perfect wreck and unmanageable log,-I deemed it prudent, though a painful cxtremity, to surrender his majesty's ship; nor was this dreadful alternative resorted to till every hope of success was removed, even beyond the reach of chance; nor till. I trust, their lordships will be aware cvery effort had been made against the enemy by myself, my brave officers and men; nor should she have been surrender. ed whilst a man lived on board had she been managcable.

I am sorry to say that our loss is severe. I find by this day's muster thirty six kilied, three of whom lingered a short time after the battle; thirty six severely wounded, nuany of whom cannot recover; and thirty two slighily wounded, who all may do well-Cotal 104.

The truly noble and animating conduct of iny officers, and the steady bravery of my crew, to the last moment of the battle, must ere: render them dear to their country. [Here Capt. Carden particularly notices the conduet of his officers, and then contioues-]

On being taken on board the enemy's ship, I ccased to wonder at the result of the battle. The United States is built with the scantling of a 74 gun ship, mouning 30 lons twenty-four pounders (English ship gums) on her main deck, and 22 forty-two pounders, carronades, with 2 long twenty-four pounder's on her quarter-deck and forecastle, howitzer grus in her tops, and a travelling carronade on her upper deck, with a complement of 478 picked men.*

The enemy has suffered much in masts, rigging, and hull above and below water; her loss in killed and wounded I am not aware of: i) I know a lieutenant and six men have been thrown overboard.

JONA.S.CARDEN。

* The frigatc United States is 176 fect deck, and 42 feet beam-lyer gun deck s 6 feet 6 inches high-she his 15 port holes on a side-ind carries 24 poun. ders on her main deek.

The Macedonian is 166 feet deck-42 feet 8 inches beam-lier gum deck is feet 10 inches high-she has 15 port holes on a side-and carries 18 poun. acrs on her main deck.

We have related an instance of Captrin Conden's henerolence-it would have een equally gratifying to have fonm lim numbumous. If this letter was not written under the perturbations of a wounded spirit, he has bethed at want of utcrity, and a littleness of soul wholly incompatible wing and in a conrersa is, Captain Carden knew the frignte United States perfect Norfolk, after examron with Captain Decutur, some time ago, whe to the difierence of metal he

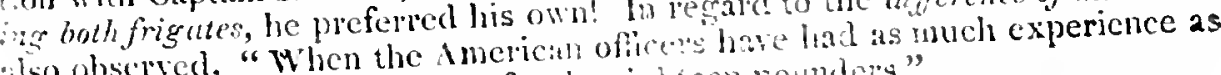

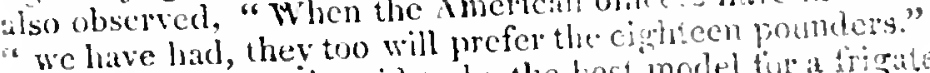

"wc have had, they too will prefere the best model fur a frigute, and was accourt-

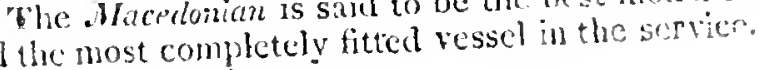




\section{Naval Dinner.}

$$
\text { New York, December } 30 .
$$

Yesterday the Corporation and Citizens of New-York gave a splendid naval dinner at the City Hotel to Captains Hulz, Decatur, and Jones, as a testimony of the high senge they entertain of their late brilliant and inexpressibly valuable exploits. The guests anounted to between four and five hundred, and it is supposed at least 300 gentlemen applied for tickets too late to be accommodated. Captain Jones was not present, not having arrived in the city.

On entrance, the room presented the appearance of a marine palace, colonaded round with the masts of ships, entwined with laurel and bearing the national flags of all the world.-Every table had upon it a ship in miniature, with the American flag displayed. In front, where the president sat, with the officers of the navy and other guests, and which was raised about three feet, there appeared an area of about 20 feet by 10 , covered with real swart, in the midst of which was a real lake of water, in which floated a miniature frigate. Back of all this hung a mainmast of a ship, 33 fect by 16 , on which was painted an eagle in opake, holding a scroll in his beak, inscribed with these words, "Our children are the proferty of our country."

His honour the Mayor presided, with Commodore Decatur seated on his right hand, and Captain Hull on his left.

After the cloth was removed, the following toasts were drank in the order in which they stand.

1. Our Country-May it ever be distinguished by wisdom in council and energy in action.-Tune, Hail Columbia.

2. 'The President of the United States-Tune, President's NTarch.

3. The Governor of the state of New York.-Tune, Tomkins' March.

4. Our $\mathrm{NAvy}_{\mathrm{A}}-$ With such an auspicious dawn, what may we not hope will be its meridian splendour.-Drank standing-Giee, The Heroes of the Ocean.

Here the mainsail back of the President was suddenly furled up, and disclosed as if by magic a transparent painting of a similar extent, representing the three victories. The Constitution taking the Guerrier, the latter in full biaze: dated Aug. 19h, 1812. The Wasp taking the Frolic, dated Oet. 18th, 1812; and the United States taking the Macedonian, dated Nor. 18. The company were electrified, and instinctively rose and gave six cheers.

5. The Union of thr. States-May it never be endangered by foreign attachments, or by internal dissensions.-Cong, Columbia's Glory.

6. American gallantry-Patriotism its stimulus; glory its object; a nation's gratitude its reward.-Song, Decatur, Hull and Jones arc here.

Here the topsail of a ship, which hung behind the vice-president, 14 feet by 12 , being suddenly clewed up, displayed a second transparency equally striking and brilliant with the first. It represented the American eagle holding three medalions; one inscribed Hull and the Guerrar, another Decatur and the Macedonia v, and the third Joves and the Frolic. The music at the same moment struck up Fankee Doodle, and nine cheers expressed the feelings of the company.

* A sentinent given by the late Commodore Decatr at a similar entertain. ment, when his two sons Steplien and Janes were present. 
7. The Memoly of those Brave Tars, who have nobly fallen in ac. quiring glory to the American navy.-Glec, Hull's Victory.

8. The army of the United States.Duett, All's Well.

9. Cummerce - the Parent of civilization-the Protectress of the arts-the Supporter of national greatness -3 cheers. Giee, We be threc poor lifuriners.

10. Our Maritime Rights-Let our government furnish the means, and our gallant tar's stand reudy to maintain them.-3 checrs. Song, Decatur's Victory.

11. The Memory of Washington-" First in war, first in peace, and first in the hearts of his countrymen." - D rank standing.

Rom - Wind gentle evergreen and form a shade,

Around the tomb where Washington is laid.

12. The spirit of patriotisu-May it always control the spirit of party,-Song, Our Country's our Shifl.

13. The Catuse of Libcrty throughout the world-May free nations respect the rights of others, while they vindicate their own-Gilec, Jicre's a heulth to all good Lasses.

\section{Sailor's Hinner.}

New York, January 8.

The gallant scamen of the frighate United States, to the number of about 400, were linded yesterdiay at the New-Slip, all very neatly dressed; and, preceled by a conmittee of the Corporation, marched in procession to the City Hotel in Broadway, where they partook of an excellent dinner in the assembly room, which was decorated in the same manner as at the grand naval dimner given on Tuesday the 29 th ult. The buatswin of the frigate presided and did the honours of the table very respectably.

Duling the procession the American colours were displayed, a complete band of music attended, the streets were crowded with citizens, and loud bursts of applause to the gallant defender's of the country, were echoed and re-echoed from every quarter.

Alier the procession had entered the assembly room, the follow. ing aldress was delivered by John F'anderbill, jun. escl. a nember of the corpolation.

"Brave American Tars!

"The Corporation of the city of New-York have ordered you this entertanment. It is griven as a tribute to your valor, displayed in the capture of the British frigate Macedomian.

"Behold yonder miniature ol youl' galliut achievement. See you"selves entwined in wreaths of laurels with the brave Hull and Jones and their valiant crews. Emblems of our gratitude-tohens of honour; which atune belong to the brave.

"The burst of aptaluse, which resounds from Creorgia to Maine, and the shout of your rictory, proclaimed in the castle and the cottage, canse us to mingle our emotions of joy with the voice of every true Ancrican, and hail you here as welcome guests.

"The mistress of the ocean, boasting of her power, clallenging to single combat, and confident of her superiority, has thrice been can quished! 
"You have taught her a lesson, that coming in contact with the hearts of Yankee oak, they were not encountering the vassals of an European tyrant.

"Remember then, ye raliant tars, that you have been rocked in freedom's cradle,-enlisted voluntarily under your country's banner's. Not torn, by a merciless press gang, from your wives and children, and dear connexions-but, fired with an ardent zeal for glory, engatged to assert the rights of your injured comtry, and punisin the haugh ty foe, who dare arrogate to themselves rights inherent to us, by the laws of nations, the laws of nature and of nature's God.

"You have nobly vindicated your country's lionour on the oceanyou have added new laurels to her fame, and your country receives it as a pledge that you are resolved to support her richts; and that her flag shall never be tarnished by cowardice, nor struck while there is a shot in the locker.

"The laurels thus obtained by your bravery, shall ever be green in the remembrance of every true American; and whilst under the command of a Decatur, whose tried valor and skill are manifest, not only in the late glorious conflict, but also, who made the bloody Turk douse his colours in disgrace, you will always be sure of victory.

"Go on, then, as you have begun, in the path of valor and duty. Your country's reward is at hand; and may every. Ancerican tar, animated by your example and success, go and clo likewise."

To this address the Boatswain replied in the following terms,-

"In behalf of my shipmates I return our sincere thanks to the Corporation of the City of New York, for the honor they have this day done us. Rest assured THAT IT WILI BE ALWAYS OUR WISH TO DESERVE THE GOOD OPINION of OUR COUNTRYMEN."

When the boatswain had finished his reply, lis shipmates in token of their approbation, marle the room ring with three hearty cheer's.

At this moment the transparent paintings exhibiting our three glorious naval victories, were suddenly displayed by the furling of the canvass, which had before concealed them. It is impossibie for pen to describe the effect which it had upon the minds of our astonished sailors; their admiration was expressed by repeated huzzas, and enthusiastic acclamations. Silence was in a few minutes restored by the boatswain's whistle, when the whole crew, to the number of 400 and upwards, commenced their attack upon an excellent dinner, which was soon demolished, and in such a manner as left no room to doubt " that they could have done much more, if more liad been required."

After clinner, silence being piped for, the president gave the following toast:

Anerican Shifls all over the Ocean.-three checrs.

Com. Decatur shortly afterwards entered the room accompanied by his first lieut. Mr. Allen, and was leceived by the seamen in a manner that evinced the affection and delight with which they beheld their brave commander.-After remaining a few mirutes, the
commodore gave as a toast,

"Free Trade and no Imfleessment."-9 cheers. 
By Mr. Allen- "Captains Jones and Hull and their brave Crews" -9 checr's.

After the commodore retired, the president gave,

Commodore Decatur and $M r$. Allen.-9 checrs.

A variety of volunteer toasts were given by different seamen in true nautical style, but with such quick succession, that we could only note the following, which we give verbatim:

The Corporation of the city of NewYork, the Orator of the day, and all the pretty Girls who like Yanke tars-May our frigates soon be turned into seventy-fours, with Decatur, Hull, and Jones at their head.-9 cheers.

Our excellent armies-May the thunder of their cannon blow the powder out of the touchholes of the Governor of Quebec. -9 cheers.

The Wooden Walls of Old England-May they serve as a turnpike road to American glory -9 cheers.

Withered be the arm-Palsied be the head, that will not defend the rights of his country. -9 cheers.

Officers and men-May each American hero receive his pay when he has earned it. -3 cheers.

May bold Decatur prove the protector of the raging main -6 cheers.

May we never feel want, and never want feeling for our countrymen. -9 cheers.

AnEmcan TARS-They carry their protection at the mouths of their cannon -3 cheers.

Captain Jones in the Wasp-Which requires English seventyfours to take an American sloop of war.- 9 cheer's.

Success to the frigate United States, and plenty of prize moncy.9 cheers.

The American Eagle-May its wings cover the ocean, and its claws grab the ships of the king of England-9 cheers.

At six o'clock, at the request of the manager's of the theatre, these jolly tars proceedcd in a body to that place of amusement, where the pit had been exclusively devoted to thei" accommodation; and where they conducted themselves with the utmost decorum; yet exhibiting the honest enthusiasm peculiar to the true sailor, which many parts of the representation were calculated to call forth.

\section{Pliladelphia, February 5, 1813. \\ Naval Dinner \\ IN HONOUR OF COMMODORE STEPHEN DECATUR.}

\section{"In battle brave;}

But still screne in all the stormy ware,

Like Heaven above the clonds! and after figlit

As merciful and hind to vanquished foes,

As al forgiving God?"

Yesterday, a splendid entertainment was given to this meritorious and gallant officer, at Renblaw's hotel, Market strect. The company, which wiss very numerous, and comprised characters of the first estimation in the city, asscmbled at $50^{\prime}$ clock, and at about half after 5 , 
sat down to a most sumptuous and elegant repast. Chicf Justice Tilghman, General Gurney, the Mayor of the city, and Alexander J. Dallas, esq. were the presiding officers of the day, who were supported in its duties by the following gentlemen, acting as a committee of arrangement, viz. George Latimer, Daniel Smith, John C. Stocker, George Harrison, Charles J. Ingersoll, Charles Ross, Joseph Hopkinson, Horace Binney, Thomas W. Francis, Daniel W. Coxe, Thomas Cadwallader.

During the banquet, and throughout the evening, the company were gratified with the performances of a full and excellent band of music, which added considerably to the exhilaration of the occasion.

In addition to the toasts drawn up for the occasion, the following volunteers were received with unbounded approbation:

Commodore Decatur, the pride of the sate of Pennsylvania.

Equal rights to all nations, and peace to the world-By the firesident.

The Memory of Commodore Decatur-the noble father of a gallant son-By $R$. M. Le zuis.

Commodore Truxton, the naval hero of 1799 and 1800-may his services never be forgotten.

The Memory of Commodore Preble-By P. S. Markley.

The American Tars-By General Wharton.

Lieutenants Allen and Nicholson, of the frigate United StatesBy A.J. Dallas, jun.

The Memory of lieutenants Bush and Funk, who bravely fell in de. fence of their country-By caftain Nicholas.

The Wash-she has given the enemy a mortal sting-By $R$. Bache, esq.

National duels-May such firinciflals as Decatur, Hull, and Jones always find such seconds as Allen, Morris, Rodgers, and Biddle-By A.J. Dallas.

The imfressed American seamen: may the chain shot discharged by their brethren, burst the chain of their bondage-By $M r$. Coofier.

May the American Eagle make the British Lion crouch, and that insolent nation feel the weight of our thirteen stripes until she shall be disposed to do us justice-By Guy Bryan.

May the Genius of freedom stand centinel on the watch tower of liberty, and hail Columbia with "All WVell"-By MTr. Markoe.

Our Country, free, sovereign and independent, as declared in 1776 by America, and acknowledged by Britain in 1783-May she become a wilderness rather than submit to any nation on earth-By General Barker.

"Rotten masts"-The bulwark of Old England is worm-eaten at last-may our Yankee Captains, like true sailors, help it to nerv sfars -By M. Nattherus.

The Genius of America-May she ever lead her sons to victoryBy Dr. Hurst.

Commodore Decatur gave-The City of Philadelphia, liberal and patriotic; her sons have reason to be proud of the place of their nativity.

The interior of the room was handsomely decorated with naval ornaments; and the front of the house was elegantly illuminated by va- 
riegated lamps, exhibiting in large characters the name of DecATer

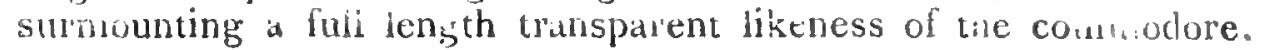
The concourse of spectator's was immense, and in the currse of the evening was increased by the arrival of a procession bearing ingts and emblems, who gave several hearty cheers, and moved through the city.

The company, fascinated by the occasion, and the hilarity it pro. duced, separated at a late hour.

An officer of the frigate United States, speaking of this victory, says, "I am aware it will be said, the flacedonian is a little ship, with he guns less than you, and is hundred men less, and carries lishter i..etall, \&c. - Well, all this is true; she is inferior in all these: but she is just such a ship as the English have achiered all their siogie sip victories in. "Twas in snch a ship that Sir Rober Earion: tr uls the

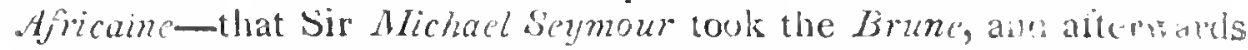
the Nimen-that Cap ali Mhine took tise Vengeance; Captitin Conk, la Forte; Captain Luzie, le Guerrier; Captain Komley, the Venus, and God know's how many others. She is in tonnage, mul, and gurs, such a ship as the English prefer to all others; and nave, till the Guerricrs loss, always thought a match for any single decked ship afloat. You will observe, the ship was just out of dock, - her masts were better than the Guerrier's.-Sinc had taken no prizes, - iter complement was full. She was not built ol fir, hirty years ago, as was said of that ship; but of the best English oak, two years since."

\section{Honour to the Brare.}

\section{LEGISLATURE OF THE UNITED STATES.}

Resolved by the Senate and Honse of Representatioes of the United States of America in Congress assimbled, That the President of the United States be, and be is herehy requested to pesent to Captain IIULI, of the firgate Constitution, Captain Decarur of the lingate United States, and Captain Jores of the slonp of war llas/l: each a grold medal, with suitable emblems and devices; and a silver medal, with like emblems and devices, to each commissioned oficer of the aloresaid vessels, in testinony of the high sense enteltained by Congrress of the gallantry, good contuct and services of the captains, officers and crews of the aforesaid vesseds in their respective conflicts with the British frigates the Gurrere and the Alacedomian, and the sloop of war Frolic: And the President is also requested to present a silver medal, with like emblens and devices, to the nearest male relative of Lieutenant $B u s h$, and one to the nearest male relative of Lieutenant Funk, in testimony of the gallantry and morit ol these deceased officers, in whom their country has sustained a loss much to be regretied.

And be it further resolect, That the President of the Cinited States be, and he hereby is requested, to present to Lientenant EiLiote. of the navy of the United States, an clegant sword, with suitable em. 
blems and devices, in testimony of the just sense entertained by Congress of his gallantry and good conduct in boarding and capturing the British brigs Detroit and Caledonia, while anchored under the protection of Fort Erie.

Approved and signed by the President, Jan. 29, 1813.

LEGISI.ATURE OF PENNSYLYANIA.

Whereas, the Conmmonwealth of Pennsylvania entertains a high seris of the distinguished skill and gallantry displayed by the officers and crews of the ships United States and lirasil, in the late victorics over a powerful enemy, and looks with peculiar pride on the share which her native sons have had in these illustrious events! 1o express these seniments to the world, and at the same time to bestow on them the most grateful reward of valour, the public approbation of their fellow citizens, therefore,

Be it resolved by the Senute and House of Refresentatives of the Conmonwealth of Permsylvania, That the Governor be, and he is hereby requested to present the thanks of this Commonwealth, to Com. modore Stranen Decatur, of the frigate United States, and to

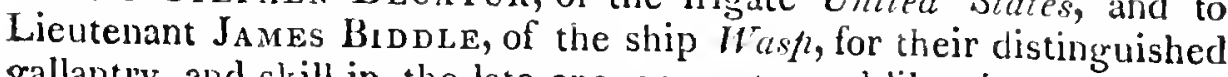
gallantry and skill in the late engagements; and likewise to procure for a present to each of them, in the name of this Commonwealth, an appropriate Sword, the expense of which shall not exceed four hun. tred dollars.

Approved and signed by the Governor, the 16tl day of February, 1813.

\section{LEGISLATURE OF MARYLAND.}

November Session, 1812.

Resolved, that the Governor of this state be and he is hereby request. ed to address, in the name of the State of Maryland, letter's to the following named officers of the Navy of the United States, expressive of the very high sense entertained of the intrepiclity, gallantry, good conduct and services of themselves and crews in their several engagements with the enemy, in which they supereminently distinguished
themselves.

To Captain Huli and Lieutenant Monris, late of the United States' frigate Constitution, in the attack, defeat and capture of the British frigate Guerrier, unprecedented in naval history.

To Captain Jones and Lieutenant Bidde, of the late United States' sloop of war $\boldsymbol{I}^{r} a \mathrm{~s} t$, in the capture of the British sloop of war Frolic, of superior force.

'To Caprain Decatur, of the United States' frigate United States, in the victory obtained over, and capture of the British frigate Macedonian.

CITY OF PHIIADELPHIA.

In Common Council, Dec. 14, 181 ?

The Select and Common Councils of the city of Priladelphia, partaking in the general sentiment of admiration for the splendid achieve- 
ment of their distinguished fellow citizen, Commodore STEPHEN Decatur, in the capture of the British frigate Macedonian, by the frigate Unitted States, under his command, do therefore resolve, as a tribute of respect for his prowess and ability, that an elegant sword, of Amcrican manufacture, be presented to him in the name of the citizens of Philadelphia.

Resolved also, That the thanks of the Select and Common Councils of the city of Philadelphia, be presented to the officers and crew of the said frigate for their gallant and meritorious conduct.

Resolved, That a joint committee of two members from each council, in conjunction with the mayor, be requested to cause the said resolution to be carried into effect.

Select council appointed Messrs. Read and Latimer-Common couneil concurred, and appointed Messr's. Mullowny and Liberty Browne.

\section{Philadelphia, January 22, 1813.}

SIR-We have the honour to forward to you the enclosed resolutions, of the Select and Common Councils of the city of Philadelphia, by which you will perceive they have ordered, that an elegant sword of American manufacture, be presented you in the name of the citizens of Philadelphia, accompanied by their thanks to the officers and erew of the frigate United States, under your command, for their gallantry and conduct, in the capture of the British frigate Macedonian.

It is truly gratifying, Sir, to the committee who were appointed in conjunction with the Mayor to carry these resolutions into effect, to accompany their transmission with expressions of the high satisfaction they feel, in so pleasing a duty, having devolved uporr them. A transaction so gallant and meritorious, as thc capture of the Macedonian by an American frigatc, would under any circumstances of ol1. country be trily grateful to us. But on the present occasion, we cannot aroid associating with it the reflection that this heroic achievement has been accomplished by a native citizen of Philadelphia, and at a time when our naval establishment, is springing from the cradel of its infancy. At a moment so interesing, the example you have set of devotion to your country cannot be without its usefulness, and must necessarily tend further to develope those naval talents, for which America is so pre-eminently distinguisherl.

Should the public service allow you a short visit to your native place, the committee will feel an additional pleasure in presenting to you in person, the above testimonial of their consideration and res. pect. We are, with scitinents of high respect, Sir, your obclient corvants,

IOHN BARKER, Mayor.

JOHN RLAD,

MHOMAS LATIMER, ('ommitter of Select Council

IOHN MULLOWNY, LIBERTY BROWNE, C'umentec of Common Comncil 


\section{CONSTITU'TION AND JAVA.}

\section{HOUSE OF REPRESEN'TATIVES OF THE UNITED STATES.}

Alonday, February 22.

To the Senate and House of Representatives of the United States.

I lay before congress a letter with accompanying ducuments from Captain Bainbridge, now commanding the United States frigate "tho Constitution" reporting his capture and destruction of the Blitish frigate "Jaz'a." The circumstances and the issue of this conibat afford another example of the professional skill and heroic spirit which pre. vail in our naval service. The signal display of both by Captain Bainbridge, his officers and crew, command the highest praise. This being the second instance in which the condition of the captured ship, by rendering it implossible to get her into port, has barred a contemplated reward for successful valor. I recommend to the consicleration of congress the equity and propriety of a general provision allowing; in such cases, both past and future, a fair proportion of the value which would accrue to the captors on the safe arrival and sale of the prize.

JAMES MADISON.

\section{United States' frigate Constitution, St. Salvador, Jan. 3, 1813.}

Sir,-I have the honour to inform you that on the 29 th ult. at $2 \mathrm{P}$. M., in south lat. 136 , and west long. 38 , about 10 leagues distance from the coast of Brazil, I fell in with and captured his B. M. frigate $J_{a z} a_{3}$ of 49 guns and upwards of 400 men, commanded by Captain Lambert, a very distinguished officer. The action lasted i hour 55 minutes, in which time the enemy was completely disnasted, not having, a spar of any kind standing. The loss on board the Constitution, rias 9 killed and 25 wounded, as per enclosed list. The enemy had $60 \mathrm{kil}$ led and 101 wounded certainly, (among the latter Captain Lambert, mortally) but by the enclosed letter, written on beard this ship, by one of the officers of the Jaza, and accidently found, it is evident that the enemy's wounded must have been much greater than as above stated, and who must have died of their wounds previously to their being removed. The letter states $60 \mathrm{killed}$ and 170 wounded.

For further details of the action I beg leave to refer you to the en. closed extracts from my Journal. The Java had, in addition to her own crew, upwards of one hundred supernumerary officers and sea. men to join the British ships of war in the East Indies: also lieutenant general Hislop, appoirited to the command of Bombay; majol Walker and captain Wood of his staff, and captain Marshall, master and commander in the British $\mathrm{Navy}$, going to the East Indies to take command of a sloop of war there.

Should I attempt to $\mathrm{d}$ ' justice by representation to the brave and rood conduct of all my officers and crew during the action, I should 
Fail in the attempt-therefore suffice it to say, that the whole of their concinct was such as to merit my hishest encomiums. I bey leave to recommend the officcrs particularly to the notice of the government, as atso the unfortunate scanicn who were wounded, and the familics of those brace men who fell in the action.

The great distance from: our own coast and the perfect wreck we made the enemy's frigate, forbade every idea of attempting to take her to the United States-I had therefore no alicrnative but burning her, which I did on the 31 st nit. afer receiving all the prisoners and their baggrage, which was very herd work, only having one boat lelt out of cight, and not one left on board the $J_{a r} \alpha$.

On blowing up the frigate $J u v a, 1$ proceeded to this place, where I bave landed an the prisoners on their parole to retarn to England, and there remain until resulariy exchanged, and not to serve in their pro!essienal capacilies in any place, or in any monner whatsoever aginst the United States of Anerica, until their exchange shall be efrected.

(bigned)

I have the honor to be, Sxc.

To the Secretary of the Navy.

\section{List of killed and wounded on board the Constitution.}

Kriled-Jonas Ongrain, seaman, Joseph Adams, do. Patrick Conner, do. Barney Hart, do. John Cheeves, * do. Mark Snow, to. John D. Allen, do. Wm. Cooper, do. Thumas Hanson, private maine.

Wounded- Wm. Bainbridģe, commander, severely; Join C. Aylwing †lient, do.; Class. I: Waldo, master's mate, do.; PetcrWoolbury,

* John Checves was mortally wounded in the late action with the Java. Whilst lying on the deck, apparently dying, the word was passed the enemy had struck. He raised himself up with one hand, gave three clicers. fell back and capiped! Heroic specimen ol the genume patrotism of American tars! He had a hother killed in the same action. We unlersiand they have left an aged and helphess nother at Mablehead who depended entirely on the fruits of their indust"' for a subsistence. [Bost. Chron.] as Sec conclusion of Account of Bimner."

† incil. at sea, Jammary 28, on board the Unitcd States frigate Constitution,

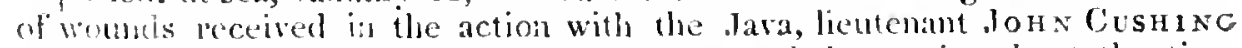
A Lw r of the United States navy. He entered the service about the time war $"$ as decturch, as a sailing master, and was prometed to a lientenant for his gallant conluet in lice acton with the Ginetrier. He was an officer of great nucrit, much cercemcd by all who had the pleasure of his acquantance. In him lis commly has suffered great loss. Ile had seen much of the world, and inponved his oplontunities of observation-possessed a strong mind, and a benevoisut risqusition.

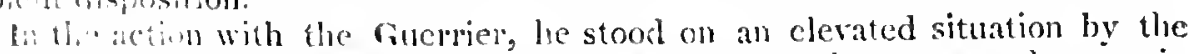
side of his combities, Morris and Bush, at the time the two ressels came in contuct. and was wounded in the lafi shoulder by a musket ball. In the late action he commanded the forecastle division; and his deliberate bravery and malked conmess throughont the contest, ganed hin the admiration of his commonder and all who had an opportunity of wituessing it. When boarders were called to lepel boarders, he mounted the quarter deck hammoek cloths; and, in the act of liring his pistol at the enemy, he received a hall throngh the same shoukler. Notwitlstanding the serious nature of his wound be continued at his pust wntil the chemy struck $\Lambda$ few datys after the action, although lat bondrg moler comsiderable debility, and the most cxcruciating pain, be left

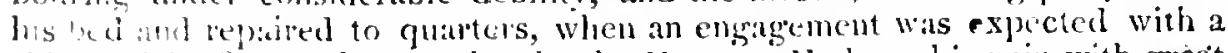
ship, which afterwards ploved to be the lloment. Ile bore his pain with great and untsual fortitucle, and expired without a groan. 
quarter master, do.; John Clements, seaman, do.; Joseph P. Cheeves, do. do.; Nich. Vintram, do. slightly; $\mathrm{W} \mathrm{m}$. Long, do. dangerously; Stephen Webb, do. do.; Reuben Sanders, do. do.; Joseph Ward, do. severely; Wm. Weaden, do. slightly, Enos Bateman, do. dangerously; Jas. D. Hammond, do. slightly; Pet. Evans, seaman, severely. Steven Shepherd, do. slightly; Abijah Eddy, do. do.; Philip Cook, do; do.; Wm. Brimblecon, do. sererely; Samuel Brown, ordinary seaman do.; Daniel Hogan, do. do.; Thomas Williams, 3d seaman, slightly; John Voyle, do. severely; Anthony Reader, private marine, slightly; John Eiwell, do. do.

(Signed)

AMIOS R. EVANS, Surgeon.

R. C. LUDLOW, Purser,

W. BAINBRIDGE.

The following is a list of his B. Majesty's Military and Naval Offcers and Crew paroled at St. Salvador (Brazils) by Commodore William Bainbridge, 3d Januiry, 1813.

1 lieutenant general, 1 major, 1 captain, military officers; 1 post captain, 1 master and commandant, 5 licutenants, 3 lientenants of marines, 1 surgeon, 2 assisting surgeons, 1 purser, 15 midshipmen, 1 gunner, 1 boatswain, 1 master, 1 carpenter, 2 captains clerks, 38 ; and 323 petty officers, seamen, marines and boys, exclusive of 9 Portuguese seamen liberated and given up to the governor of St. Salvador, and 3 passengers, private characters, whom the Commodore did not consider prisoners of war, and permitted the $m$ to land without any restraint.

\section{Extract from Commodore Bainbridge's Joumal.}

Tuesday December 29, 1812-At 9 A. M. discovered two strange sails on the weather bow. At 10 discovered the strange sails to be ships: one of them stood in for the land, and the other stood off shore, in a direction towards us. At $1045, \mathrm{~A}$. M. we tacked ship to the northward and westward, and stood for the sail standing towards us; at $11 \mathrm{~A}$. M. tacked to the southward and eastward, haled up the mainsail and took in the royals. At 11 so, made the private signal for the day, which was not answered, and then set the mainsail and royals to draw the strange sail off from the neutrul coast, and separate her from the sail iir company.

IVednesday, 30th Dec. ("nautical time), lat. 13, 6, S. long. 31, W. ten leagues from the coast of Brazil, commenced with clear weather and moderate breezes from E.N.E.-hoisted our ensign and pendant. At 15 minutes past meridian, the ship hoisted her colours-an English ensign, having a signal fiying at main.

At 126, P. M. being sufficiently from the land, and finding the ship to be an English frigate, took in the mainsail and royuls, tacked ship, and stood for the enemy. At 150, P. ML the enemy bore down with an intention of raking us, which we avoided by wearing. At 2, P. M. the enemy being within half a mile of us, and to windward, and having haled down his colours, except the union jack at the mizenmast head, induced me to give orders to the officer of the third division to fire a gun a-head of the enemy, to make him shew his colours, which being done, brought on a fire from us of the whole 
broadside, on which the encmy hoisted his colours, and immediately returned our fire. A general action, with round and grape, then commenced; the enemy keeping at a much greater distance than I wished; but could not bring him to a closer action, without exposing ourselves to several rake3. Considerable manœurres were made by both vesscls to rake and avoid being raked. The following minutes were taken during the action:-

"At 2 10, P. M. commenced the action within good grape and cannister distance, the enemy to windward, (but much farther than I wished.) At 230 , our wheel was shot entirely away. At 240 , determined to close with the enemy, notwithstanding his raking. Set the fore and mainsail, and luffed up close to him. At 250 , the enemy's jibboom got foul of our mizen rigging. At 3, the head of the enemy's bowsprit and jilboom shot away by us. At 35 , shot away the enemy's foremast by the board. At 315 , shot away his main topmast just above the cap. At 340 , shot away the gaft and spanker boom. At 355 , shot away his mizen mast ncarly by the board. At 4 , having silenced the fire of the enemy conpletely, and his colours in the main rigging being down, we supposed he had struck, - we then haled down courses and shot ahead to repair our rigging, which was extremely cut; leaving the enemy a complete wrcck: soon after discovered that the enemy's flag was still flying. Hove too to repair some of our damage. At 20 minutes past 4, the enemy's mainmast went nearly by the board. At 50 minutes past 4 , wore ship and stood for the encmy. At 25 minutes past 5 , gnt very close to the enemy in a very effectual raking position, athwart his bows, and was at the very instant of raking him, when he most prudently struck his flag-for, had he suffered the broadside to have raked him, his additional loss must have been extremely great -as he laid an un ranageable wreck upon the watcr."*

* 'The following correspondence exhibits the character of captain Bainbridge in a light so honourable, and so well calculated to exalt the national character, that we are happy in the opportumity of giving it publicity. Nat. Int.

\section{GENERAL. HISLOP TO COMMODORE BAINBRIDGE.}

Sit. Sulvador, . Fanuary 3, 181 S.

D) $\mathrm{AR}$ SIR-I am justly penetrated with the fullest sense of your very hand. some and kind treatment, crer since the fate of war placed me in your power, and I beg once more to renew to you my sincerest acknowledgments for the same.

Your acquiescence with my request in granting me my parole, with the ofliecrs of my statf, adkled to the obligutions I had previouslyexperienced, claims from me this additional tribute of my thanks. May I now finally flatter myselt, that in the further extension of your generous and humane feclings, in the alleviations of the misfortunes of war, that you will have the goodness to fultil the only wisl and request I am now most anxious to see completed, by enlarge ing on their panole (on the same conditions you have aceded to with respect (1) ingself) all the ollicer's of the Java still on board your ship-a favour I shall never rease duly to appreciate by your acpliesecnce therelo. I hate the honour (1) subscribe myself, dear sir, your most obliged and very humble servant.

Comnaluse Brimbridge.

$$
\text { (signed) }
$$

T. HISLOP.

ANSWIR OT COMMODORE BAINBRIDGE.

Tinted States frigate Constitution, Si. Sultudar, 3al .Ianuary, 1813.

Dearstr-l have received your letter of this date, conveying sentiments of vale lecelings for my treatinent towads you since the fite of war placed you 


\section{Size of the Java.}

The Java is rated in Steel's List a' 38 gun frigate. Her real force was 28 eighteen pounder's on the main deck-14 thirty-two pounders on the quarter deck-4 thirty-two pounder's, and 2 large twelve poun. ders on the forecastle-and one shifting gun, a twenty-four pounder.

The British rate their ships from the number of guns on a particular deck; and a frigate carrying 28 eighteen pounders on her main deck, is regularly called by them a 38 , which rate has frequently fifty-two mounted.

There are on board the Constitution some of the Jav'a's shot, from which it has been ascertained, that there is scarcely three pounds difference between her eighteens and the American twenty-fours, so cal-

in my power. The kind expressions which you have been pleased to use, are justly appreciated by me, and far overbalance those common civilities shewn by me, and which are always due to prisoners. I regret that the lumbered state of my ship prevented me from making you as comfortable on board as I sincerely wished to have done. I have complied with your last request, respecting paroling all the officers of the Jara: In doing so, your desire, in adidtion to my disposition to ameliorate as much as possible the situation of those officers, considerably influenced me.

Permit me to tender you (notwithstanding our respective countries are at war) assurances of sincere esteem and high respect, and to assure you that $\mathbf{I}$ shall feel at all times highly gratified in hearing of or from you. With ferrent wishes for the recovery of the gallant captain Lambert, I hare the honour to subscribe myself, very respectfully, \&c.

(Signed)

Lieut. Gen. Hislop, of the British army.

WI. BAINBRIDGE.

\section{GENERAL HISLOP TO COMMODORE BAINBRIDGE.}

St. Saliador, 4th fanucum, 1813.

DearSir-Allow me once more to express my sincerest acknowledgments for this last instance of your kind attention to my wishes, by having complied with my request in behalf of the officers of the Jara. Lientenant Chads delivered to me your very polite and obliging letter, and be assured that I shall feel no less gratification at all times to heal of and from you than that which you are so good as to express you will derive in receiving information respecting myself.

May I request now that you will be so good as to cause to be looked for a small chest, containing articles of plate, more valuable to me on account of having been presented to me by the colony of Demarara, where I commanded for several year's.

(Signed)

I have the honour to be, \&ic.

Commodore Bainbridge.

Lieutenant Chads presents his compliments to commodore Bainbridge, and is extremely sorry to inform him, Captain Lambert died a short time since.

St. Salvador, .Monday, 11 o'clock.

\section{COMNODORE BAINBRIDGE TO LIEUTENANT CHADS.}

January $4,1813$.

Commodore Bainbridge has learnt with real sorrow the death of Ciptain Lam. bert. Though a political enemy, he could not but greatly respect himfor the brave defence he made with his ship: and commodore bainbridge takes this occasion to observe in justice to lieutenant Chads, who fought the Java after captain Lambert was wounded, that he did every thing for the defence of that ship which a brare and skilful officer coula do, and that firther resistance would have been a wanton effusion of human bloot? 
led; and that the thirty-two pound shot of the Jaza is heavier than the thirty-two pound shot of the C'onstitution.

The officer's of the $J_{a r} a$. while on board the Constitution, mentioned that this firigate was formerly the French silip La Renommee, taken off Madagascar, May 20, 1811, in company with $L a$ Neriede, after a severe action, by the Phoebe, Astrea, and Galatea. At the time of capture, the Renommee mounted 44 guns-the British added five guns.

Boston Febuary, 20.

On Thursday at 12 o'cicck, Commodore BAINBRIDGE landed at the long wharf from the frigate Constitution, amidst acclamations, and roaring of cannon from the shore. All the way from the end of the pier up to the Exchange Coffec House was decorated with colors and streamers. In State Street they were strung across from the opposite buildings, while the windows and balconies of the houses were filled with ladies, and the tops of the houses were covered with spectators and an immense crowd filled the streets, so as to render it difficult for the military escort to march. The Commodore was dis. inguished by his noble figure, and his walking uncovered. On his right hand was the pride of on navy, the veteran Com. Ropgers, and on his left, Brig. Gen. Wezles, then followed the brave Capiain Huli, Col. BLAKE, and a number of officers and citizens; but the crowd was so immense that it was difficult to keep the order of procession. The bind of music in the balcony of the State bank, and the music of the New- England Guards had a fine chicet, especially when they struck up Yankee doodle. On these occasions, the Bostonians, notwithstanding British infuence, feel themselves Americans. Bun herhill, Saratoga, Yorktown, and the glorious period of '76, fill thei: brave licarts, and make them cry out for seventy fours.

\section{Dinner in honour of Commodore Bainbridge.}

Boston, Murch 3.-Yesterday a splendid Public Dinner was given. in the exrhange Coffee House, to Commodore BaIn ProdE and the offress of the United States frigate Constitution, for their gallant achievement in the capture of the lsritish first rate frigate $J$ ar a; - to which Com. Rogers, Capts. Hull and Suith, and the officers of the squadron now in our port were invited...The procession was formed in Faruiel Hall, by Majol Tiken, and was escorted amidst the ipplauses of our townsmen, to the Coffes House, by a battalion composed of the Boston Light Infantry and the Winslow Blnes, commanded by Col Sergeant. The Hall was completely filled. The Hon. Cisistopher Gore presided-The Hon. Itarison G. Otis, Hun. Isriel Thorndike, Arnold Velles Esr. Thomis I. Winthrop Lisq. Hon. Peter C. Brooks, and Win. Sullivan Esq. assisted as VicePresidents.

ihe entertainment was sumptuous, and the sty le in which it was rot up did credit to Mr. Jones, who provided it.

Before sicting down to table the blessing; of Almighty God was aske! in a most implessive manner by the Rev. Mr. Holley.

After thanks were returned, the Hon. Mr. Fore addressed the sontlemen present on the occasion. In a rery elegint and impressive: 
inanner he displayed the high honor and distinguished benefits resulking from the brilliant achievements of our gatlant heroes, and tendering to Com. Bainbridge and his officers the gratulation of the company, he proposed as a toast the health of their distinguished guest, which was drank amid plaudits that mace the welkin ring-The Commodore replied in a very intcresting manner; after which the following toasts wele received with the highest demonstrations of pleasure and gratification.

1. Our Country -its honour is our pride - the support of its honor is our $\mathrm{NAVY}_{\mathrm{A}}$.

2. The President of the United States of America.

3. The Covernor of the Commonwealth-His name indicates his character-Strong in intellect-Strong in principle-and Strong in the affection of the people.

4. The Battly of the 29th of December-The sun of Ame. rican glory then first beamed in the soltheru bemisphere- May its lustre increase through the successire periods of time, and in all the divisions of the globe.

5. The Memory of Lieut. Aycwin, and his companions in arms, who fell in the action with the Jara-

"When fall the brave, their brilliant doom,

A ge after age shall memory keep,

And chase the darkness from the tomb."

6. Opportunity to the brare-May the frigrtes President and Congress be soon rated in England as "Seventy-fours in disguise."

7. The gallant spirit of our Nuval Chiets-ln battle, learless-in victory, modest and humane.

8. The Memory of Washington-His spirit approves us from the skies-We will rever forget that his valor and his wisdom have prepared our triumphs.

9. The American flag protected by true smerican blood-It will protect all who sail under it.

10. The defenceless coasts of New-England-May those whom it concerns remember, that it is treason to give harbors to our enemies.

11. Massachuselts, firm and honest-ienacious of her righismindful of her obligations though not disgraced—assailed, but not dismayed-disquicted, but not in despair.

12. Independent America-She wants no instruction in the Freedom of the seas from the Tyrant of the land-her gallant TARS can vindicate alone the honor of her flag-they need no insidious aid from a despot.

13. The Crew of the Constitution-May our country never be reluctant to spend money for those who spend their lives for us.

14. Our National Rulers-May they learn from our victories on the ocean, that the path to honorable peace, is not througin the wilderness, but over the Atlantic.

15. The gloly that our Hull, Jones, Decatur and Baribridge, have brought from the Ocean, shall bcam with brighter lustre, when the brave who have sought, shall share their fame.

16. That Skill and Valor which deserve victory-that Magnanimity * hich commands the sratitude of the conquered. 
By Commodore Bainbridge-The Town of Boston, the Cradle of American Independence.

By Commodore Rodgers-The Citizens of the State of Massachu. setts-May their patriotic spirit and hospitable feeling find a suitable return in the breasts of their countrymen.

By Caftain Hull-The Enemy-should he attempt to enter our harbor, may he be taught that we have a Bunker hill, and Bostonians to defend it.

Aftcr the fifth toast, the President of the day announced in an affecting and eloquent address, that the money arising from the subscription which was usually appropriated to decorations, had been on this accasion reserved for the benefit of the widow Cheeves, who had lost in the battle with the Java, her only two sons, her stay and support; and he offered this to the Commodorc as an apology for an omission of decorations of the hall, as had been usual, and doubted not it would be acceptable. The Commodore expressed his grateful sense of the compliment implied in the apology; and all present felt that the compliment was justly due.

\section{Honour to the Brave.}

\section{IEGISLATURE OF MASSACHUSETTS.}

In Senate, February 19.

Resoived, That the thanks of this Senate be given to Commodore WILLIAM BAINBRIDGE, and the officers and crew of the frigate Constitution under lis command, for their brilliant achievement, in capturing and destroying his Britannic Majesty's frigate $J a v a-$ and that the Commodore be requested to communicate the same to his officers and erew, with an assurance from this branch of the legislature, that they will hold in grateful remembrance those who fell in fighting for the essential and violated rights of their country.

Resoleted, That the President of the Scnate cause an attested copy of this resolution to be transmitted to Commodore Bainbridge.

\section{SAMUEL DANA, President.}

The following neat and dignified answer was returned by Commodore Bainbridge.

\section{United States frigate Constitution,}

Ha!bour of Boston, February 20, 1813.

"S S thanks from the Senate of the Commonwealth of Massachusetts to myself, ofticers, and crew, for capturing and destroying the British frigate Jaz'a.

"To incrit and receive the approbation of our country, ever has, and ever will be our highest ambition.

"I am sir, very respectluily, your obedient servant,

The IION. SAMUEL DAXA.

IVM. BAINBRIDGE.

On motion of the IIon. Mr. Otis, it was voted, unanimously, that the answer be entered on the Journal of the Senate. 
In the House of Representatives, February 13.

Whereas every event which reflects iustre upon the Anerican name, and contributes to elevate the national character in the view of foreign powers, ought to be distinguisher and nonoured by the people of the United States: And whereas the brilliunt victories achieved by our gallant navy since the commencement of the present war with Great Britain, are highly calculated to produce that effect, and while they demonstrate to the nation, the wistlom and patrionism of that policy which projected and created a navy, they strongly urge upon the national goverument, the importance of encouraging and increasing that species of defence. It becomes the representatives of the people of Massachusetts (whatever may be their opinions in relation to the present war) to testify their high approbation of the gallant and able conduct of those officers and crews of the navy, to whora the fortunate opportunities have occurred of giving reputation to the American arms, and of signalizing their own valour, enterprise, and nautical skill. Therefore,

Resolved, as the opinion of this house, That commodore Bainbridge and Decatur, captains Hull and Jones, of the United States Navy, their officers and crews, in the splendid victories by them recently obtained over the British ships of war the Java, Macedonian, Guerrier, and Frolic, and in their generous conduct to their captured enemies, have acquired for themselves a distinguished title to that consideration and applause of their feliow citizens, which is due to a heroic and able discharge of duty, and which is the legitimate reward of the brave man who devotes his life to the service of his country.

Ordered, That the Speaker be requested to communicate the above resolve with its preamble to the respective naval officers to which it has reference.

Attest,

B POLLARD, Clerk.

An attested copy of this resolve was communicated to each of the Naval Officers mentioned, in an appropriate letter from the hon. Tim. othy Bigelow, Speaker of the House.

Is Common Council (Nerv York), Merch 1, 1813.-The following resolution was proposed by Mis. Bracket, and unanimously adopted.

In testinony of the high sense entertained by the Common Council, of the gallantry and skill of Commodore WM. BAINBRIDGE, and his officers and crew, on board the United States' frigate Constitution, in the late capture and destruction of his Britannic majesty's frigate, the Java; whereby now laurels have been acquired by our gallant na$\mathrm{vy}$; and a new instance afforded of the practical utility of that kind of defence, for the protection and encouragement of the important commercial interests of our country-

Therefore Resolved, That the freedom of the city be presented to Commodore BaInEuIDGe, in a golden box; and that his lortrait be obtained, and set up in the gallery of portuaits, belonging to this city; and that the thanks of the Common Council be presented to his off:cer's and crew, who were engaged in this achievenent, so lronatuble to themselves and the nation. 


\title{
EPITOME OF' THE NAVAL VICTORIES,
}

\author{
AND A BRIEF SKETCH OF THE PUBLIC TESTIMONIALS OF RRSFET \\ OFFERED TO OUR GALLANT OFFICERS AND SEAMEN.
}

[The following article is so necessary to the completion of this publication, and is so highly interesting, that we offer no apology for giving it entire. Though there will be some repetition, yet it notices many public testimonials of res pect that had escaped our attention: and it exhibits all we have gizen in so comprehensive a view that the whole is seen at a glance.]

\section{FROM THE AURORA.}

To commemorate a new and important era in the anmals of the United States, an event hishy sratifying to every American, and which the historian of this country wili record with the most lively exultation, I beg leave to submit to the perusal of my fellow citizens the subjoined epitome of the naval victories that have taken place since the commencement of the war against Great Britain, and a Lrief sketch of the public testimonials of respect offered to our gallant officers and seamen, all of whom have crowned themselves with never faring lanels.

The statements exhibit a fair narration of facts, taken altogether from official documents, and so far as information can be obtained, that of the engagements is even acknowledged by the enemy as perfecly correct in all its parts. They give unequirocal evidence of the bravery and skill of our gallant little navy, who have advanced the honor of their comntry to the very zenith of glory, and produced a glow of naval ardor and enthusiasril, which I am satisfied can never know of diminution. They also prove that we stand equally univalled in that high national character and feeling which constitutes the great strength and grandeur of a nation.- Here our liberality has been often questioned, and by none more than these same vanquished Britons-they have even made it a subject fit for their amusement and ridicule. How severely painful to their feelings then must it be, to see that they are chosen as the rery instruments to produce convicion of thcir own errors, and how grateful ought they to feel to those who have placed them in the path of honest truth.

'The splendid achievements of oul' sons of the ocean have already witisin a lew months, in every instance where opportunity occurred, wrested from the arrogant self-styled invincible mistress of the seas, a naval trophy, nor can the naval records of any country on earth prodice such examples of complete discomfitures of an eneny-discomfitues which their own papers inform us have caused in their rabils the " most mortifying reflections" and " most serious apprelemsions."

To dwell on the distingrished services of our brave tars, who have absolntely given birth to new lopes and feelings, is indeed a theme limhly checring to the hearts of every American, nor is it less encouraging to witness that valor and good conduct does not in this comntly go unnoliced, but on the contrary calls forth a large share of highly respectable attention and honourable reward.

NEPTUNI: 
Absiract of Actions fought between shifs of war of the United Sates and Great Britain, since the commencement of the ruch.

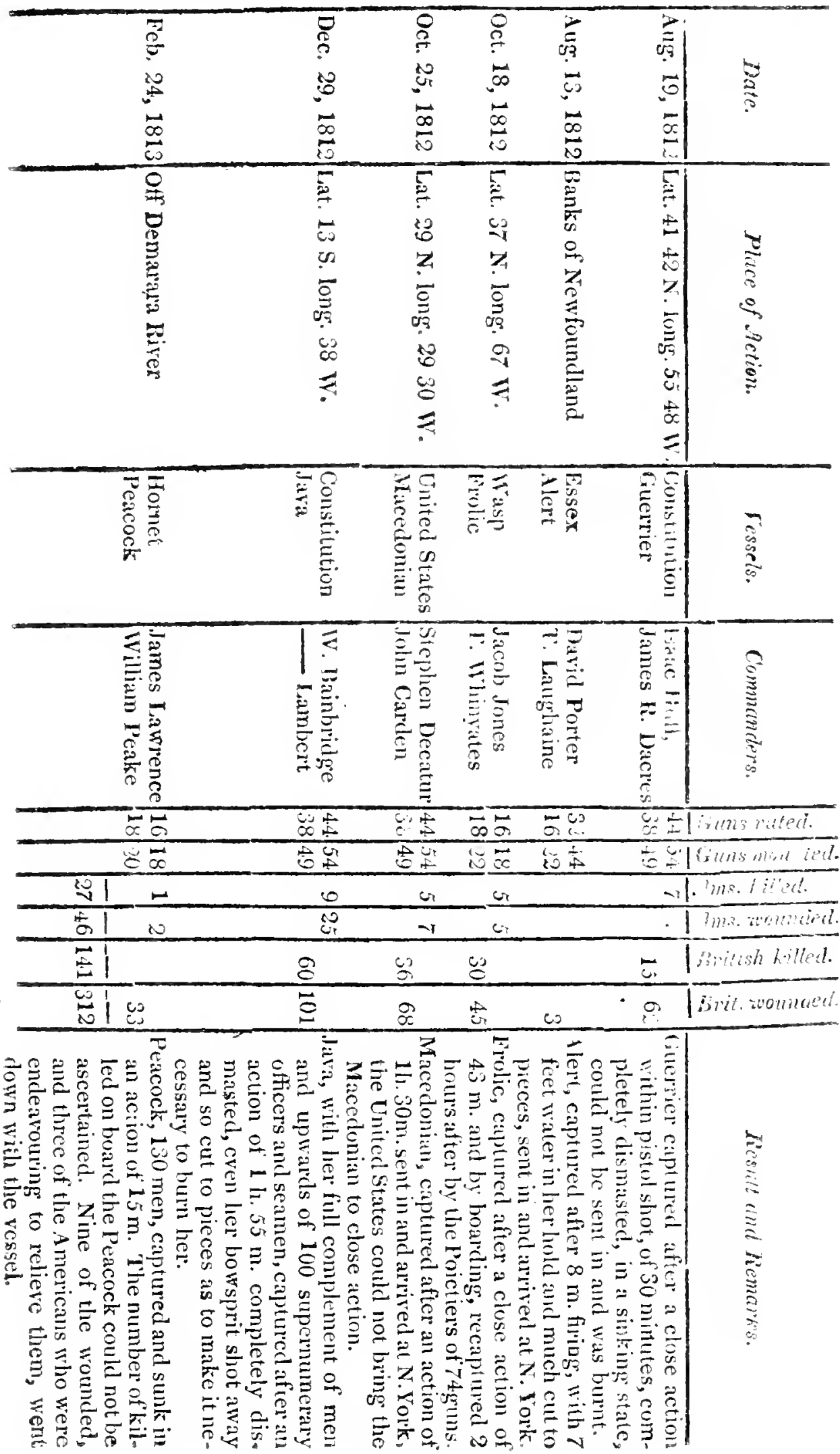




\section{RECAPITULATION.}

American loss-rilled 27 -wounded 46

Britush loss_- killed 150-wounded 312

$$
\text { Difference } \overline{123} \quad \overline{266} \text {-together } 389
$$

A brief statement of the testimonials of public respect tendered to captain 1 HuLL, officers and crew, of the Constitution; captain J. Jones, ofticers and crew, of the Wasp; commodores. Deca t un, officcrs and crew, of the United

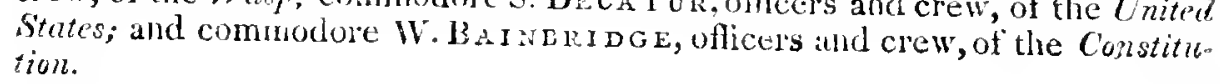

\section{To captain I. Hull, offecrs and creav of the Constitution for the caluture of the British frigate Guerrier.}

The congress of the United States voted $\$ 50,000$ and their thanks to caplain Hull, officers and crew-also a go d medal to captain Hull, alud siver medials to each of lle officers, with proper devices, emblematic of the viciory.

The citizens of Philadelphia subscribed an elegant piece of plate to captain Fill, and a piece of plate to $\mathrm{C}$. Morris, first lieutenant. The young nien of the socisty of Friends, at Philadelphia, subscribed to the relutives of those who vere killed.

Tue common council of New York voted a public dinner and the fruedom of the city, in a goid box, to captain Ifull, and thanks to the officers and crew. Bill

The citizens of New York subscribed a public dinner to captain

The order of Cincinnati admitted captain Hull an honorary member of their society.

The legrislature of Now York voted their thanks to captain Hull, officels anci crew.

The counciis of Albany voted the freedom of the city to captain Ha!l. and thatiss to officers and crew.

The councils of Suranmah voted their thanks to captain Hull, offcers and crew.

Tise citizens of Charleston, S. C. subscribed a handsome piece of plate to captain Iitll.

The house of representatives of Massachusetts voted their thanks to coptin Hull, of

The inhoditants of Poltand subscribed an elegant swold to lieutenant liadisuresh.

The citizens of Boston subscribed a public dinney to captain Hull and officers.

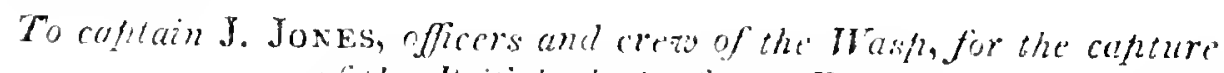 of the british stosp of awer Frotir.}

The congress of the United States voted $82 j, 000$ and their thanks to captain Jone of oficers and crew, also a gold nedal to captain Jones, and siver nockals io each of the oficers with proper devices, enblematic of the viciory.

The citizous of Philudelphia subscribed an elegant sword and a pullic climer to captin Joncs and a sword to eacla of the lieutemants. 
The legislature of Pennsylvania voted an elegant sword to lieuten. ant Biddle.

The common council of New York voted the freerlom of the city and an elegant sword to captain Jones, as also a public dinner, and thanks to officers and crew.

The citizens of New York subscribed a public dinner.

The legislature of $\mathrm{New}$ York voted their thanks to captain Jones, officers and crew.

The house of representatives of Massachusetts vated their thaniss to captain Jones, officers and crew.

The order of Cincinnati at New York, admitted captain Joncs, an honorary member of their society.

The councils of Savannah voted their thanks to captain Jones, officers and crew.

The Icgislature of Delaware voted a superb piece of plate to caps tan Jones, and thanks to officers and crew.

To commodore S. Decatur, officers and crevo of the United States for the cafture of the British frigate Macedonian.

The congress of the United States, voted their thanks to commodore Decatur, officers and crew-also a gold medal to commodore Decatur, and silver medals to each of the officer's, with proper devices emblematic of the victory.

The legislature of Pennsylvania voted their thanks and an clegant sword to commodore Decatur.

The councils of Philadelphia roted an elegant sword to commodore Decatur, and thanks to officers and crew.

The citizens of Philadelphia subscribed a public dinner.

A township laid out adjoining Northumberland county line, to be called Decatur township.

The legislature of New York roted thanks to commodore Decatur, officers and crew.

The common council of New York voted a public dinner, and the freedom of the city in a gold box to commodore Decatur-that his portrait be procured and set up in the gallery of portraits belonging to the city - that a public dinner be given to all the crew of the ship, and thanks to commodore Decatur, officers and crew.

The managers of the theatre at New York, invited all the crew of the ship to the theatre, and appropriated the pit for their accommodation.

The cilizens of New York subscribed a public dinner to commo dore Decatur.

The order of the Cincinnati at New York, admitted commodore Decatur an honorary member of their society.

The corporation of New London presented their thanks to commodore Decatur, officels and crew.

The councils of Savannah voted their thanks to commodore Decatur, officers and crew.

The house of representatives of Massachusetts voted their thanks io commodore Decatur, officers and crew.

The legislature of Virginia voted an elegant sword to commodore 
Decatur, and swords to lieutenant $W . H . A l l e n_{9}$ and lieutenant $\mathscr{T}$. Nicholson.

To commodore WV. BAINBRIDGE, officers and crew of the Constitution, for the cafture of the British frigate Java.

The congress of the United States voted 50,000 dollars and thein thanks to commodore Bainbridse, officers and crew-also a gold medal to commodore Bainbridge, and silver medals to each of the officers, with proper devices emblematic of the victory.

The citize is of Philadelphia subscribed an elegant piece of plate commodore Bainbridge.

The kgislature of New York voted their thanks to commodore Bainbridge, officers and crew.

The citizens of Boston subscribed a public dinner to commodore Bainbridge and officer's.

The senate and house of representatives of Massachusetts voted their thanks to commodore Bainbridge, officers and crew.

\section{LIST OF THE NAVY OF THE UNITED STATES.}

Names. Guns. Commandirs. Names. Guns. Commanders.

\begin{tabular}{lll|lll} 
United States & 44 & Decatur. & Essex & 32 & Porter. \\
Constitution & 44 & Bainbridge. & Adams & 32 & Norris. \\
President & 44 & Rodgers. & Ship John Adams 20 & Ludlow. \\
Macedonian & 38 & Jones. & Alert & 20 & \\
Congress & 36 & Smith. & Hornet & 18 & Lawrence* \\
Chesapeake & 36 & Evans. & Brig Argus & 16 & Sinclair. \\
Constellation & 36 & Stewart. & Syren & 16 & \\
New York & 36 & (repairing). & Oneida & 16 & Woolsey. \\
Boston & 36 & (repairing). & Enterprize & 14 & Blakeney.
\end{tabular}

Besides the above, commodore Chauncey has under his command several small vessels on the lakes. There are also a number of small vessels at different stations, and from 160 to 180 gun boats.

* Appointed to the cornmand of the Constitution, in place of captain Bainbridge, who is to superintend the building of a seventy-four. 


\title{
SONGS ANU ODES.
}

\author{
arancone
}

INVOCATION

Tune-"Banish sorrow."

Comrades, join the flag of glory, Cheerly tread the deck of fame,

Earn a place in future story, Seek and win a warrior's name.

Yankee tars can laugh at dangers: While the roaring mountain wave

Teems with carnage-they are strangers To a deed that is not biare.

May our banner'd stars, as ever. splendidly o'er fireemen burn,

Till the aight of war is over, Till the dasu of peace return.

\section{IMPROMPTU.}

On the captuwe of the Guervier.

Ilark, hark! o'el ocean's subject wave, Wafted by th' enamour'd gale,

The loud chorus of the brave, "Columbia's sons prevail."”

List! you'll hear our hero's voice, Courage breathes in every breath, Inull! who gives the only clioice, "Instant victory or death."

"Rush like lightning on the foe; Gall them will incessant fire,

Board and conquer at a blow, Board and conquer, or expire."

Loud and louder peals the roar, Swift and certan is their aim;

The ocean's red with gallant gor's; IIigh it blazons with their fane.

IIush! a freeman's dying groan! Be the flag a moment furl'd,

But ralor ne'er is overthrownIhe's immortal in each world.

Warriors! smile upon your wounds; See vur Morris fight and bleed;

Your applauding country sounds, "Love and glory are your nreed."

Shout! the British lion's fall! Shout! the star-flag streams along! Mercy! is the Briton's call, Tictory! Columbia's songy!
ODE sung at the dinner given to the officers of the United States frigate Constitution, after the victory uver the Britisl firigate Guerrier.

Tune-" Ie .Mariner's of Englanc!"

Britannia's gallant streamers,

Float proudly o'er the tide;

And fairly wave Columbia's stripes,

In battle, side by side;

And ne'er did bolder foemen meet,

Where ocean's surges pour.

O'er the tide now they ride,

While the bellowing hunders roar,

While the camnon's fire is fishing fast,

And the bell'wing thunders ront.

When Yankec meets the Britian,

Whose blood congenial flows,

By Heav'n crosted to be friends,

By fortune render'd foes;

IIard then must be the battle fray,

Fre well the fight is o'er.

Now they ride, side by side,

While the bell'wing thunders roar,

While the camon's fire is fisthing fast,

And the bell'wing thunder's rodr.

Still, still for noble England,

bold DAcRes' streamer's fly;

thd, for Columbia, gallant II 2 L's,

As proudly and as high.

Nor louder rings the battle din,

Hore thick the volumes pour,

Still they ridc, sicte by side,

While the bell'wing thunders roar,

While the canmon's fire is flashin's fast,

And the bell'wing thunders roar.

Why lulls Bricannia's thunder,

That waked the wa'ry war?

Wby stays that gallant Guerrier,

Whose streamer wav'd so fitir?

That streamer drinks the ocean's ware?

'That warrior's fight is o'er!!

Still they ride. side by side,

While Columbia's thunders roar,

While her cannon's tire is Hashing fitst

And her Yankee thunders roar.

Hark! 'tis the Briton's lee gun?

Ne'er bolder warrior kneel'd!

And ne'er to gallant marinere 
Did brave seamen yield.

Proud be the sires, whose hardy bors

Then fell, to fight no more;

With the brase, mid the wave,

When the camon's thunder roar,

Their spirits then shall trim the blast,

And swell the thunder's roar.

Tain were the cheers of Britons,

Treil hearts did vainly swell,

Where vitule, skill and bravery,

Witl gallant Morf is feil.

'I hat heart, so well in buttle tri'd.

Along the Noorish shore,

Again o'er the main,

When Coltumbia's thunders roas,

Shall prove its Vankee spirit true,

When Columbia's thunders roar.

Hence be ou floating bulwatks

'Those oaks our mountains yeld;

'Tis mintry Hearen's plain dectee-

Then take the wat'p ficld!

To occari's farthest barliep then

Your Whit'ning sail shail pour;

Safie you'll mate o'or the ticte,

While Columbia's thunders roar;

Why br canron's fire is flishmig fast,

And her Yankee thunders roar.

Hull's Naval Victory, or Huz=a for ine Constitation.

Tune.-Pazl Jones's Fictory.

Ye true sons of freedom, give ear to my song,

While the praise of brave HuLe I attempt to prolons,

I et each bold-hearted liero now fill up his glass,

And our favourite sentiment rapidly pass.

cHORUS.

With our brave noble Captain, we'll still plow the main,

We'll fight and we'll conquer again and ag:ali.

With a fine springring hreeze, our sails we soon bent,

And with hearts full of joy to the ocean we wem,

In the fam'd Constitution, a tight and stanch boat,

As evel was seen on the water afloat.

With our brave noble Calptain we plow'd the deep main,

And when he conmands we alde ready agaill.

On the nineteenth of August, a sail we espi'i,

We love to, and soon she came up along sicie;
The drum beat to quarters, to quarters. we run,

ind each tar bravely swore to stand fast to his gun.

Our Captain so brave as we sail'd on the main,

Now bid us a harvest of glory to gain.

A broadside the foe quickly into us pour'd,

We relurn'd 'em the farour direct on the word,

Each heart was undaunted, no bosom knew fear,

And we car'd not a snap for the sallcy Guerier.

With our noble Commander we fought on the main,

And we'll conquer with him when he bids us again.

The balls now flew thick, and quite warm was the play,

Their masts and their ligging we soon shot away,

IVe shater'd theil hull with all possible specd,

With our good spunky "bull-dlogs, of true Iankee breed."

'Twas this with our Captain we fought on the main,

With him a rich harvest of glory to gain.

The blood flom the eneny's scuppers ran fast,

11 hopes of subduing us now were quite past:

So they wisely concluded, "by hob or" by nob,

"That 'was best to give o'er what they thought a had job."

With our true noble Captain, we'll fight on the main,

And we hope that with him, we'll soon conquer again.

The Britons had seldom before seen the like,

For we rak'd 'cm so clcan, they'd no culrues to strike.

So a gun from the lee they were forc'd to let fly,

I'o intorm us they didn't quite all wish to die.

'T was thus with our Captain we fought on the main,

And we're ready, brave boys, to fight with him agitin.

In twenty-five minutes, the business was done,

For they did'nt quite relish such true rankee lun;

So we kindly receiv'd "cm on board our good slip, 
Many cursing the day when they took / But since we're took, and burnt and sunt. their litst trip.

With our brave noble Captain we'll still plough the main,

We'll fight and we'll conquer again and again.

Now homeward we're bound, with a fa voring breeze,

As full of good humour and mirth as you please,

Each true hearted sailor partakes of the glass,

And drinks off a health to his farourite liss.

With our brave noblc captain we've piow'd the deep main,

SVith him we the laurels of ylory did gain.

Now success to the good Constitution, a boat,

Which her crew will defend while a plank is afloat,

Who never will finch, or in'duty e'er lag,

But will stick to the last by the American flag.

So truc to our colours we'll ever remain,

And w'll conquer for freedom again and again.

When again we shall plow o'er Neptune's blue wave,

May honours still circle the brows of the brave,

And should our bold foe wish to give us a pull,

We'll show 'em the good Constitution and HULL.

And now with three cheers ere we sail to the main,

We will greet our brave Captain again and again.

\section{NEIV YANKEE DOODLE.}

the British long have rul'd the scas, With hauglity gasconading,

And chaunting songs, their feats to praise While others they're degrading.

$$
\text { сноrus. }
$$

Yankee doodle, fire away, Cannon, loud as thunder,

Frombrare Drcatur, Jores and HULL, Makes Johnny Bull krock under.

Now we can sing, and clamnt libewise, of Yankee still in fighting;

Wehold, DEcatur, with his prize, Bold Britons now are striking.

Vankee doodle, dic.

rhe British liought we had not spunt Yo ty. them n! the orean;

They've got another notion.

Yankee doodk, Scc.

'They'll find they've not Monsier to meet,

But Yinkee boys of mettle;

Who will their measures all rlefeat, Unless they shortly settle.

Yankee doodle, \&c.

To press our men they claim the right,

liut blast their imposition;

We'll let the rascals know, we'll fight

in preference to submission.

Lankee cloodle, B.c.

Huzza, my boy's, we'l! fight away,

Until they cry pecari;

Or, with our well-am'd Tankce play,

Soon send them to Old Dary.

$$
\text { CHORUS. }
$$

Yankee doodle, clack away,

With cainnon loud as thunder;

Our Yankee boys will show them play,

Till Johnny Bull knock under.

\section{LILLE-BULL-ERO.}

When Guerrier, Dacres, from Halifax satilod,

He boasted that he the occan would sweep,

And to his mast-head some cantas he nail'd,

To scare every Yankee that furrow'd the deep.

CHORUS.

American seamen as well as ouryeomen;

Will fight for the flag of the nation,

And old Johnny Bull, may yet have his full,

When he visits his Yankce relation-

Witl his Lilli-bull-ero lilli-bull-a.

Near the banks of Newfoundland the Britisly fell in

With a brave little crew of American tars,

Bo:h frigates well found, both crews witli hearts swelling,

Sone shrunk from the conflict, none dreaded thei: sear's.

American seamen, Sc.

The high sounding threat, fying at the mist head,

Appal'd not the hearts of a newly ship'd crew,

Each man to his gun adranc'd without dread,

Like heroes they fought, to America true. American scamen, sce.

The Britisl: had boasted for twenty long rears,

By force neary equal they never wets beat; 
That the Fronch selum meet them without min: lears,

"And nlwars tuke care to secure a retreat."

American seamen, \&c.

The gon? Constitution commanded by IIELL,

Away threw no powder and wasted mo b:ill,

Lach shot that she fird spoke loul to John Bull,

Ship to ship, my brave mesmates, ou foe must som fill,

American seaman, Re.

The daturel which Britain so nobly har "oris,

Achicr'al br ber Nelsons, St. Vincents and billes,

From her brows in a monent was gallanty toln,

Iy the hrave captain IULA in this game of sweenstakes.

American scamen, \&c.

Lomplife in our ralliant dofonders at sea,

success to the soldiers "ho guard our firmlicis,

May Rueliec feel the slock of men born tiree,

And canala tremble before our thes cheers.

American Seamen, Sc.

Political squalbbles may each other proreke.

I hate thil damn'd jargon-give me but the lacis

Who will stand to their quarters, amid fine and smoke,

Tho' sumounded by foes, who will never look sit?.

Amorican scamen, 总.

since war is the wond, let us stran everyerre,

Po himble the lion, our greatness incresise,

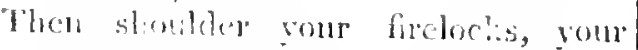
rolmesy prescrese,

since the lodter the witr, boys, the sooner comes price.

hullucunseanen, ixc.

siong.

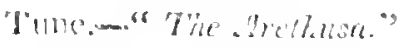

I olurblia's sous prepare suitu,

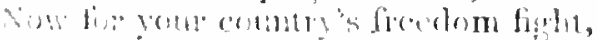

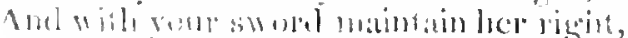

"i aines purde and peesecution:

Ind white you sonure our hamghty toes,

the sign the mantial deceds of throse,
Whose metal tri'd,

Soon lower'd the pride

Of Dacres, who biave Hull defi'd

On board the Constitution.

Nineteenth of sugust, half past two,

Iorl past meridian came in view,

The finerrier frigate! with her crew

All fip'd with resolution;

The horsting chieftain bent his course.

Resulv"il to put his tlureats in force,

And with his grums,

sublue the sons,

of Yankees who no danger shuns.

On board the Constitution.

Our gallant ship now swiftly flies,

And crery man his gur supplies,

While on commander cheerly cries,

Erince your resolution;

Witla ardour each to action springs,

whilst with luree cheers the welkin rings;

Our fues amaz'd

With wonder gaz'd,

To see Columbia's standard rais'd

(u) board the Constitution.

The Guerrici's balls flew thick and hot

Around us, Which we answered not,

But steer'd till within pistol shot,

Resolved on execution.

Our first broildside like thunder loar'd,

And brought her mizen by the board,

ller main mast too

And fore mast flew,

In pieces, while onr jovial crew

Huz:ald the Constitution.

When I) A res first received this check, And saw the Guerrier a wreck,

llimself a prisoner on the deck,

lis ship's crew in confusion;

Percuised the rankee boys on lonared,

With grief beletd the mion lower'd,

All hupe now fled,

lle sigrlings satil

The Gon of with to rictory led

Brare lleta in the constitution.

This Briton oft hat made his boisst?

Ha. with his erew, a closen host,

Pour till destruction round our coast.

Alicl work a rerolution;

Unel be his prib: a challenge sent.

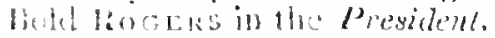

II islins to met

lim in lete-ateter,

Or wine his eytal liom one flect,

such was the Constitution.

Columbia's sons! esch jovial soul, Whose growere hreast contemes control.

liejoiring whel the sparkling bowl,

While wime flows in protision: 
FirstWashracton! our country's boast; | While HuLL, whose brave bosom with

The Congress next, shall be our. toast, Our third is due

Brave Hull and crew;

Then all who hold our rights in view, And guard the Constitution.

THE' SOVEREIGNTY OF THEOCEAN.'

By the trident of Neptune, brave HuLL cried, let's stear,

Is points out the track of the bullying Guerrier;

Should we meet her, brave boys, seamen's rights be the cry,

We fight to defend them, to live free or die.

The famed Constitution thro' the billows now flew,

While the spray to the tars was refreshing as dew,

To quicken their sense of the insult they felt

In the boast of the Guerrier's not being the Belt.

Each patriot bosom now throb'd with delight,

When joy ful the cry was-a sail is in sight!

Three cheers, cried the captain, my lads, 'tis the foe,

British fride shall be this day by rankees laid low.

Behold now the Guerrier, of Britain the boast,

Ifer topsails aback-and each tar to his post,

While Dacres a flag did display from each mast,

To show that as Britons they'd fight to the last.

The American stars now aloft were unfurl'd,

With her stripes at the mizen-peak as proof to the world

'That lowe'el British pride might blus. ter or fret,

The sun of her glory should that ciay be set.

Now prim'd with ambition her guns loated full,

The Guerricr's broadsides roar'd tremendous at $\mathrm{Hu}$ r.L,

Not only the hero, ship and crew to annoy,

But the Hull of our frecdom, our liglits to destroy.

As the brave Constitution her focman drew nigh,

Each beart beat with valor, joy glisten'd each eye: glory did swell,

Cried, "free trade, seamen's rights, now let every shot tell."

Quick as lightning, and fatal as its dread ed power,

Destruction and death on the Guerricr did shower,

While the groans of the dying were heard in the blast,

The word was "take aim, boys, away with her mast."

The genius of Britain will long rue the day,

The Gierrier"s a wreck "in the trough of the sea,"

Her laurels are wither'd-her boasting is done,

Submissive, to leeward, she fires her last gun.

Now brilliant the stars of America shine,

Fame, honour and glory, brave HuLL, they are thine,

You have Nepiune amaz'd, caus'd Britain to weep,

While Fonkecs triumphantly sail o'er the deep.

The sea, like the air, by great Nature's decrec,

Was given in common and shall ever be tiree,

But if Ocean's a turmpike whore Britain kecps toll,

Hule, Jones and Decatur will pay for the whole.

The Yankee's Descrigtion of the Battle betroen thi Constitution and Guerrier.

'Tune-“Pacily's Description of Pizarro."

From the Halifax station a bully there came,

To take, o1 be taken, bold Dacres by name;

And who, but a Fanker, he met on the way?

says be, wo'nt yon stop, and take some tetc-a-tete?

Then, Dacres got mad, thus addressing" his clew,

You see that d-d flag, which is red, white and blue!

IVe must drum all to quarters: prepare for the figint;

For, in taking that ship, it will make me is Enight 
Fhe two after-topsails were back'd with / And, dropping a-ster's, lie call'd out te the yard,

They drimm'd all to quarters, each man on lis guard.

Saying sirike, vou d-d Yankec, we'll make yon, with ease;

But, a man, illey call'd livLı, said, $O$, no! if you please.

Then Hozh, like a hero, before them appeared,

And, ill a short speech, he his sailors thus cheer'd;

We'll batter her sides, and will do the nexe thing,

That's conquer the bully, and laugh at the king.

Ilis men of "d with their hats, and gave lim at clieer,

Swore to stick by thcir HuLd, white a seaman could steer;

Then, went to llieir quarters, with mutual delight,

And swore they would die for a secman's fiee right.

Then Dacres stepp'd up, told his men not to fear!

You see, in the main-topsail is wrote the Guerrier;

We will give them such balls, as they never have felt,

And make them remember the ship Little Jicli.

Then up to each mast-head, he straight sent a flaxs,

Which lonk'd, all the world, like a proud British brig;

But IIULl, being complaisant, scht up) but one,

And bicl every man to be true to his guus.

then we crowded all sail and came along-side,

We well fed our bull-dogs, of true Yankee pride;

Broanside on broadside upon tlıem wo potir'd.

rill Cannon's loud moutlis at eacli other rour'd.

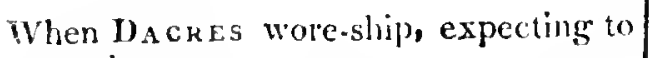
rake;

But he, in his hurry, found out his mistake;

We lufl'd round his bow; and we caught lis jib-boom,

And raking lim aft, we soon gave him lis drom.

'Ihon 1) A cres look'd wild, thus sheath ing hus sword,

lle foumd that his masts were all gone b. ble board:

Come up, and be $d-d$, fire a gun to the leeward.

Then, the sons of Columbia gave three hical'ty cheers,

Which biterly stung all these English. men's ear's;

Saying, we bid a defiance to your guns and your thag,

And bid you no more on the occan to brag:

Here's a health to brave $\mathbf{H o L} \mathbf{L}$, and his merry men, all,

Who will fight for their cause, while there's powder and ball.

They will stick to their commerce, and do what is right,

And show all the world, that the Iankees can figlit,

\section{DECATUR'S VICTORY.}

Sung by Mr. Ilaldinge of the New The. atre, at the representation in lonour of the victory.

$$
\text { Tune-" Arethusa." }
$$

Columbians strike th' enliv'ning strair,

To cheer the hero home again,

Gover'd with laurels from the main,

Huzza for the brave DECATUR.

He met the focman on the wave,

He tausht the skilfui and the brave,

llow well the tars,

Unus'd to wars,

Could sline amidst the din of battle,

And while the grorious camnon's ratte,

Huzza for the brave DEcatup.

Brave was the .Incedminn's crew,

Tlue Captain lie was valliant too;

And every British lueart was true,

When they met the bold Deca t ur:

and while the glorious cannon's train.

Re-echocd o'er the distant nain,

The Britons proud,

Exclain'd aloud;

"Sce, see, we've fil'd the foeman's side."

But still our gallant tars replied:

Huzza for the brave Decatur.

The battle's fury soon is o'er,

I'the vivid light'nings gleam no mole,

. Ind silent is the cannon's road,

Huzza for the brave Decatur.

In streams of blood their flag descends.

his race full many a Briton cuds,

Our planks ale tightit

Uul' ressel's right,

Ind every sailor at his post,

Exclaims in joy and woncler lost,

Iuzza for the brave Decat th. 
YANIEE FROLICS-A NEW SONC.

No more of your blathering nonsense, 'lout the Nelsons of old Johnny Bull; r'll sing you a song, 'pon my conscience,

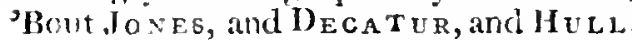
Dad Neytume las long, with vexation, Beleld with what insolent pride, The tulfulent, billow-re asid nation llas ain'd to continl his salt tide. Sing lather away jonted and aisy, By my soul, at the ganie lob-or-nob, Ii a very few minutes we'll plase ye, Because we take work be the job.

There was Dacres, at vauting and bossting,

lis equat you'll seldom come near;

But Hul betwixt smoking and roasting, Dispatch'd his proud frigate Guerries! Such treament in hom, wits a wonder, Which serv'd his prond spirit to choke; And, when to the bo tom our thinder Had sent her, we law igd at the joke. Sing lather away joneel and i.isy, Brate Ituld, at the gane uob-us.nob, Is the boy that uill surely amaze ye; So weil h': can finish the job.

$r$ 'other clay, worse than gout, fit, ol. cholic,

The Hasp, with Rodgens, Bid due and Joxes.

So terribly stung the poor Frolice

As left hel-but bare skin and bones.

She struck, but what conld she do better;

For time, there was none to delay,

Indecd it must terribly fret her

$T_{0}$ see she could not run away.

Sing lather away jonteel and aisy,

Brave Joxes, at the grame hob-or-nob,

Is the lad that will surely amaze ye,

So well he can work by the job.

Now, to augment our brave little navy, And add to the strength of each state,

Decatur, without sauce or gravy, Has dress'd Alexander the Great!* By my soul, to prerent further trouble, And save a disgriaceful downfall, since they find all resistance a bubble, 'They'll strike without fighting at all. Sing lather away jonteel and aisy, DECA T U R, to pliay hob-ol--nob, Will in sevemteen minutes amaze yeHuzza, 'twas a quick finished job.

ODE, sung at the dinner given at Boston in honour of commodore Bainbridge.

Tune.-. $Y_{e}$.Mariners of Englund."

Brave hearts of ocean chivalrj,

Who, late in arms have stood

'The Macedonian.
Victorious o'er the bravest foe, Whose thunder wakes the food!

Ye wise, who sought Fame's proudes: height,

And twice arraign'd the goal!

Again, o'er the main,

Shall your conq'ring thunders roll,

And your bamners float victoriously, And your condu'ling thunders roli,

Mark, how your ship triumphantly II er native billows lave

Where first she gare her virgin form, Is rapture to the wave:

Twice bold Britammia's hearts of oak

IJave own'd her"stern control;

And again o'er the main,

Shall her conq'ring thunders roll, And her banners float victoriously, And her conq'ring thunders roll.

When first again, for battle, Ye bade your thunders swell, I spirit clad, in armor, stood, Whese once an hero fell.

't stemly frown'd upon the foe, und show'd the scar it bore;

'ill agann o'er the main,

Your tinunder ceas'd to roar,

ind your banners wav'd rictorionsly.

While your tliunders ceas'd to roar.

Bush, 'twas thy gallant spirit,

That lef $t$ its realins on high,

To hear Columbia's battle rage,

To see her streamers fly.

That spirit when the fight was done,

Aloft the tidings bore,

llow again, o'er' the main,

Your cong'ring guns did roar,

And your banner's wav'd victoriously,

And your conq'ring gruns did roatr.

Fame! wreath again thy laurels,

Like HuL L's, for ever fail';

Such garlands, on his manly brows,

Shall noble BAINBRIDGE wear;

The same their bamer and their deck,

The same their daring soul,

And the same be their fame,

Where their conq'ring thunders soll,

And their banners float victoriously,

And their conq'ring thunders roll."

Iligh, on the rolls of glory,

With honor's cloubly crown'd,

By those, whose sires are yet unborn,

Shall ArLw N's name be found.

'The spirits of the brave, who live

On thine eternal scroll;

Again o'er the main,

When they hear their thunders roll.

Shall trin those banners to the breeze;

While the conq'ring thunders roll. 
"Ve Marinels of England," The brave applaud the brave; Our bays, with cypress would we twine, "To deck your lambert's grave, But, since 'tis ours to meet ye, foes, Our gallant friends of yore, Again, o'er the main, Sliall our conq'ring thunders roar', And our bamers float victoriously, And our conq'ring thunder's roar.

Fame, ready twine sucly grarlinds, As crown the brave, to day; For here are ocean warr:or's, As good and brave as they.

When fortune leads them, where the foe Now sweep the surges o'er;

Again o'er the main,

Shall our cong'ring thunders roar, And our bamers float victoriously, And our conq'ing thunders roar.

\section{FINALE.}

\section{OUR NAYY. Tune-" Irail liberty."}

On wings of glory, swift as light, The sound of battle came, The gallant II TLL in glorious fight, llas won the wreaths of fame

let brave Columbia's noble band lyith hearts mited rise,
Swear to protect their native land, Till sacred freedom dies.

Let brave DECATUR's dauntless breast, With patriot ardor slow, And, in the garb of vict'ry drest, Triumphant blast the foe.

Let brave Columbia's noble band, \&c.

And RoGERs with his gallant clew,

Oer the wide ocean ride,

$\therefore$ prove their loyal spirit true,

And erush old Albion's pricle.

Let brave Columbia's noble band, \&ic.

Then hail another Guerrier thele,

With roaring broadsides, hall,

And while the thunder rends the air, See Briton's sons turn pale.

Let brave Calumbia's noble band, \&ac:

The day is ours, my boys, huzza,

'The great commander cries,

While all responsive, roar buzza,

With pieasure sparkling eyes.

Let blave Columbia's noble band, \&.c.

Thus shall Columbia's fame be spread.

Her heav'n born Eagle soar,

Her deeds of glory silull be read,

When tyrants are no more.

Let brave Columbia's noble band With hearts united rise,

Swear to protect their native land 'Till sacred freedom dies. 




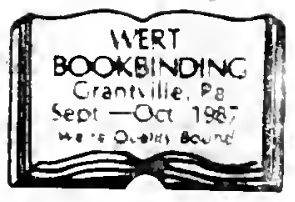




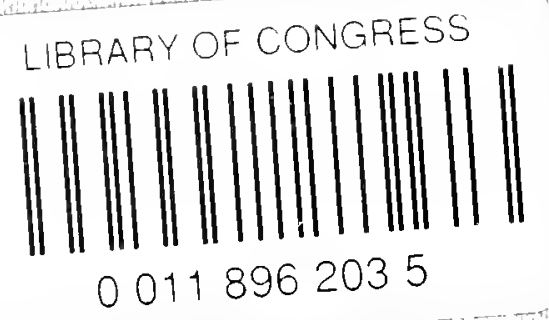

